\title{
Glycine Enolates: The Effect of Formation of Iminium lons to Simple Ketones on a-Amino Carbon Acidity and a Comparison with Pyridoxal Iminium lons
}

\author{
Juan Crugeiras ${ }^{\#}$, Ana Rios ${ }^{\#,}{ }^{,}$, Enrique Riveiros ${ }^{\#}$, Tina L. Amyes ${ }^{\dagger}$, and John P. Richard ${ }^{\dagger},{ }^{*}$ \\ \# Departamento de Química Física, Facultad de Química, Universidad de Santiago, 15782 Santiago de \\ Compostela, Spain \\ $\dagger$ Department of Chemistry, University at Buffalo, SUNY, Buffalo, NY 14260, USA
}

\section{Abstract}

Equilibrium constants in $\mathrm{D}_{2} \mathrm{O}$ were determined by ${ }^{1} \mathrm{H}-\mathrm{NMR}$ analyses for formation of imines/ iminium ions from addition of glycine methyl ester to acetone and from addition of glycine to phenylglyoxylate. First-order rate constants, also determined by ${ }^{1} \mathrm{H} N \mathrm{NR}$, are reported for deuterium exchange between solvent $\mathrm{D}_{2} \mathrm{O}$ and the $\alpha$-amino carbon of glycine methyl ester and glycine in the presence of increasing concentrations of ketone and Brønsted bases. These rate and equilibrium data were used to calculate second-order rate constants for deprotonation by $\mathrm{DO}^{-}$and by Brønsted bases of the $\alpha$-imino carbon of the ketone adducts. Formation of the iminium ion between acetone and glycine methyl ester and between phenylglyoxylate and glycine is estimated to cause 7 unit and 16 unit decreases, respectively, in the $\mathrm{p} K_{\mathrm{a}} \mathrm{s}$ of 21 and 29 for deprotonation of the parent carbon acids. The effect of formation of iminium ions to phenylglyoxylate and to 5 '-deoxypyridoxal (DPL) [Toth, K.; Richard, J. P. J. Am. Chem. Soc. 2007, 129, 3013-3021] on the carbon acidity of glycine is similar. However, DPL is a much better catalyst than phenylglyoxylate of deprotonation of glycine, because of the exceptionally large thermodynamic driving force for conversion of the amino acid and DPL to the reactive iminium ion.

\section{Introduction}

We are interested in characterizing the kinetic and thermodynamic barriers for deprotonation of the $\alpha$-amino carbon of amino acids ${ }^{1-3}$ and peptides ${ }^{4}$ in water and in understanding the mechanism by which enzymes lower these barriers in catalysis of deprotonation of amino acids. 1,5 There are enzymes which catalyze deprotonation of amino acids such as alanine, ${ }^{6,7}$ glutamate ${ }^{8-10}$ and diaminopimelate, ${ }^{11}$ without any assistance from an electrophilic cofactor to stabilize negative charge at the $\alpha$-amino carbon. The results of experimental, $1,5,12,13$ computational, ${ }^{10}$ and $\mathrm{X}$-ray crystallographic studies ${ }^{11}$ are converging to show that the thermodynamic barrier for conversion of the protein bound amino acid to the zwitterionic carbanion reaction intermediate is strongly favored by catalysis at a nonpolar enzyme active site. $^{5}$

E-mail: E-mail: qfarr2cn@usc.es; E-mail: jrichard@chem.buffalo.edu.

Supporting Information Available: Table $\mathrm{S} 1$ of second-order rate constants $(k \mathrm{~B})$ hyd for general base-catalyzed hydrolysis of Nprotonated glycine methyl ester; Table $\mathrm{S} 2$ of first-order rate constants, $k_{\mathrm{ex}}$, for exchange for deuterium of the first $\alpha$-proton of glycine methyl ester in the presence of acetone and buffer catalysts; Table S3 of first-order rate constants, $k_{\mathrm{ex}}$, for exchange for deuterium of the first $\alpha$-proton of glycine in the presence of phenylglyoxylate and buffer catalysts. This material is available free of charge via the Internet at http://pubs.acs.org. 
Pyridoxal 5'-phosphate (PLP) is an extraordinary electrophilic catalyst of carbon deprotonation of $\alpha$-amino acids in water, ${ }^{14,15}$ and at enzyme active sites. ${ }^{16}$ The first step in the mechanism for covalent catalysis by PLP is formation of an imine between the amino acid and PLP. Formation of this adduct labilizes all of the bonds of the $\alpha$-imino carbon, because heterolytic bond cleavage with loss of $\mathrm{H}^{+}, \mathrm{CO}_{2}$ or $\mathrm{R}^{+}$gives a carbanion that is strongly stabilized by delocalization of negative charge onto the pyridine ring of the cofactor.

The presence of the pyruvoyl prosthetic group at enzymes that catalyze decarboxylation of amino acids suggests that this ketone is an effective electrophilic catalyst of reactions that proceed through $\alpha$-amino carbanion intermediates. ${ }^{17-20}$ However, there is little known about the relative mechanistic imperatives for electrophilic catalysis of deprotonation of amino acids by simple carbonyl compounds and by PLP, because there have been few model studies of such catalysis by the former electrophiles. 21,22 We have reported that the simple ketone acetone possesses a significant fraction of the power of PLP as a catalyst of the deprotonation of amino acids, because of the strong carbon acidity of the iminium ion adduct 1-H (Chart 1). 2 We report here the full results from our earlier communication and extensive new data for Brønsted base catalysis of deprotonation of $\mathbf{1 - H}$ and for catalysis of deprotonation of glycine by phenylglyoxylate (Chart 1). A comparison of data for catalysis of the deprotonation of glycine by phenylglyoxylate and for catalysis by 5 -deoxypyridoxal (DPL) ${ }^{15}$ shows that the $\alpha$-amino carbon acidity of adducts to phenylglyoxylate (2-H, Chart 1 ) and to DPL are similar. In other words, the problem of increasing the acidity of the $\alpha$-amino carbon of amino acids may be solved by formation of iminium ion adducts to carbonyl compounds with structures much simpler than that for PLP. On the other hand, we find that DPL is a much better catalyst of carbon deprotonation than phenylglyoxylate at $\mathrm{pD} 7$, so that there are other properties of PLP, which confer it a unique role as a cofactor in catalysis of bioorganic reactions.

\section{EXPERIMENTAL}

\section{Materials}

Deuterium chloride (37 wt \%, 99.5\% D), potassium deuterioxide (40 wt \%, $98+\% \mathrm{D}$ ), deuterium oxide $(99.9 \% \mathrm{D})$, acetone- $\mathrm{d}_{6}(99.9$ atom \% D), glycine methyl ester hydrochloride, quinuclidine hydrochloride, 3-quinuclidinol, 3-chloroquinuclidine hydrochloride, 1,1,1,3,3,3hexafluoro-2-propanol (HFIP) and 2,2,2-trifluoroethanol (TFE) were from Aldrich. Glycine and phenylglyoxylic acid were purchased from Fluka. The 3-substituted quinuclidines were purified by recrystallization from the following solvents: quinuclidine hydrochloride, ethanol; 3-quinuclidinol, acetone and 3-chloroquinuclidine hydrochloride, 1:1 (v:v) methanol/ propanol. All other chemicals were reagent grade and were used without further purification.

\section{General Methods}

The acidic protons of glycine, glycine methyl ester hydrochloride, $\mathrm{K}_{2} \mathrm{HPO}_{4}, \mathrm{KH}_{2} \mathrm{PO}_{4}$, the hydrochlorides of quinuclidine and 3-chloroquinuclidine and the hydroxyl proton of 3quinuclidinol were exchanged for deuterium, as described previously, before preparing solutions in $\mathrm{D}_{2} \mathrm{O} .{ }^{1,4}$ Phenylglyoxylic acid, methoxyacetic acid, HFIP and TFE were dissolved directly in $\mathrm{D}_{2} \mathrm{O}$, which resulted in $<1$-atom \% increases in the protium content of this solvent. Phosphate buffers were prepared by mixing stock solutions of $\mathrm{K}_{2} \mathrm{DPO}_{4}$ and $\mathrm{KD}_{2} \mathrm{PO}_{4}$ in $\mathrm{D}_{2} \mathrm{O}$ at $I=1.0(\mathrm{KCl})$ to give the desired acid/base ratio. Acetate buffers were prepared by dissolving the basic form of the buffer in $\mathrm{D}_{2} \mathrm{O}$ that contains $\mathrm{KCl}$ followed by addition of $\mathrm{DCl}$ to give the desired acid/base ratio at $I=1.0(\mathrm{KCl})$. Buffers of methoxyacetate, HFIP and TFE were prepared by dissolving their acidic forms and $\mathrm{KCl}$ in $\mathrm{D}_{2} \mathrm{O}$ followed by addition of $\mathrm{KOD}$ to give the desired acid/base ratio at $I=1.0(\mathrm{KCl})$. Solutions of quinuclidine, 3-quinuclidinol and 3 -chloroquinuclidine cations in phosphate buffer at $\mathrm{pD}=7.6$ were prepared by mixing the 
tertiary ammonium ion $(I=1.0, \mathrm{KCl})$ and phosphate buffer $(I=1.0, \mathrm{KCl})$ and $1 \mathrm{M} \mathrm{KCl}$ to give $0.1 \mathrm{M}$ buffer.

The $\mathrm{pH}$ and $\mathrm{pD}$ were determined at $25^{\circ} \mathrm{C}$ using an Orion Model $720 \mathrm{~A} \mathrm{pH}$ meter equipped with a Radiometer GK2321C combination electrode $\left(\gamma_{\mathrm{OL}}=0.79\right)$ or an Orion model $350 \mathrm{pH}$ meter equipped with a Radiometer pHC4006-9 electrode $\left(\gamma_{\mathrm{OL}}=0.78\right)$. Values of $\mathrm{pD}$ were obtained by adding 0.4 to the observed $\mathrm{pH}$ meter reading. ${ }^{23}$ The concentration of deuterioxide ion at any $\mathrm{pD}$ was calculated using eq 1 , where $K_{\mathrm{w}}=10^{-14.87}$ is the ion product of deuterium oxide at $25^{\circ} \mathrm{C}$ and $\gamma_{\mathrm{OL}}$ is the apparent activity coefficient of $\mathrm{DO}^{-}$under our experimental conditions. 24,25

$$
\left[\mathrm{DO}^{-}\right]=\frac{10^{\mathrm{pD}-\mathrm{p} K_{w}}}{\gamma_{\mathrm{OL}}}
$$

\section{${ }^{1} \mathrm{H}$ NMR Analyses}

${ }^{1} \mathrm{H}$ NMR spectra at $500 \mathrm{MHz}$ were recorded in $\mathrm{D}_{2} \mathrm{O}$ on a Varian Unity Inova $500 \mathrm{NMR}$ spectrometer or a Bruker AMX500 NMR spectrometer as described in previous work. 1,24, 26,27 In all cases, the relaxation delay between pulses was at least 10-fold longer than the longest relaxation time of the protons of the substrates being examined $\left(T_{1}=4 \mathrm{~s}\right.$ for glycine methyl ester and glycine). Spectra were obtained with a sweep width of $2600 \mathrm{~Hz}$, a $90^{\circ}$ pulse angle and an acquisition time of $6 \mathrm{~s}$. Baselines were corrected for drift before integration of the peaks. Chemical shifts are reported relative to HOD at $4.67 \mathrm{ppm}$ or $\left(\mathrm{CH}_{3}\right)_{4} \mathrm{~N}^{+}$at $2.94 \mathrm{ppm}$.

\section{Determination of Equilibrium Constants}

The position of the equilibrium for formation of imines to glycine and glycine methyl ester was determined by ${ }^{1} \mathrm{H}$ NMR analysis at $25^{\circ} \mathrm{C}$. The formation of the imine of glycine methyl ester was monitored in solutions that contained $0.1 \mathrm{M}$ glycine methyl ester and $3.0 \mathrm{M}$ acetone at $I=1.0(\mathrm{KCl})$. The formation of the imine of glycine was monitored in solutions that contained $0.1-2.0 \mathrm{M}$ glycine, $0.8 \mathrm{M}$ phenylglyoxylate at $I=1.0(\mathrm{KCl})$. The $\mathrm{pD}$ was maintained by use of $0.10 \mathrm{M}$ of the following buffers: methoxyacetic acid, $\mathrm{pD} 3.3-4.8$; acetic acid, $\mathrm{pD} 4.5-6$; phosphate, pD 6.2-8; HFIP, pD 8.9 and TFE, pD 12-13. Glycine methyl ester served as the buffer for experiments at $\mathrm{pD}>8$. Hydrolysis of the ester at $\mathrm{pD}<8.8$ was not significant $(<6 \%)$ during the $c a$. one hour time needed to record NMR spectra, but the breakdown of the ester at higher $\mathrm{pD}$ prevented the determination of equilibrium constants for imine/iminium ion formation.

$$
\left(K_{\text {add }}\right)_{\text {obsd }}=\frac{[\mathbf{X}-\mathbf{D}]_{\mathrm{T}}}{[\text { Gly }]_{\mathrm{T}}[\text { Ketone }]}=\frac{A_{\mathrm{CH}_{2}}^{\mathrm{X}-\mathbf{D}}}{A_{\mathrm{CH}_{2}}^{\mathrm{Gly}}[\text { Ketone }]} \quad \mathbf{X}=\mathbf{1 , 2}
$$

Values of the observed equilibrium constant $\left(K_{\text {add }}\right)_{\text {obsd }}\left(\mathrm{M}^{-1}\right)$ for imine formation were determined from the ratio of the integrated areas of the peaks for the methylene protons of the imine product ( $\left.A_{\mathrm{CH}_{2}}^{\mathrm{X}-\mathrm{D}}\right)$, and of the reactant glycine or glycine methyl ester ( $A_{\mathrm{CH}_{2}}^{\mathrm{Gly}}$, eq 2). The relative equilibrium concentration of the glycine-phenylglyoxylate imine at $\mathrm{pD}>8$ was determined 24 hours after mixing the reactants, in order to ensure that chemical equilibrium had been reached. The rate of phenylglyoxylate-catalyzed exchange of the $\alpha-\mathrm{CH}_{2}$ hydrogen of glycine for solvent deuterium at pD $12-13$ is competitive with imine formation.

However, ${ }^{1} \mathrm{H}$ NMR analysis shows that deuterium enrichment of the $\alpha-\mathrm{CH}_{2}$ groups of glycine 
and of the phenylglyoxylate imine are the same within experimental error. Therefore, there is no enrichment of either species with deuterium, and the ratio of the concentrations of glycine and its imine to phenylglyoxylate anion may be determined as the ratio of the sum of integrated peak areas for the $-\mathrm{CH}_{2}$ - and -CHD- groups from ${ }^{1} \mathrm{H}$ NMR analyses.

\section{Kinetic Measurements}

All deuterium exchange reactions were carried out in $\mathrm{D}_{2} \mathrm{O}$ at $25{ }^{\circ} \mathrm{C}$ and $I=1.0(\mathrm{KCl})$. The reactions were initiated by preparing solutions of the carbon acid, ketone catalyst and the buffer at the same $\mathrm{pD}$ and $I=1.0(\mathrm{KCl})$ and mixing these reagents to give a final carbon acid concentration of $15 \mathrm{mM}$. A slow downward drift in the $\mathrm{pD}$ was observed during the deuterium exchange reactions of glycine methyl ester, due to the competing hydrolysis of the ester. ${ }^{2}$ The $\mathrm{pD}$ of these solutions was monitored and maintained within 0.05 unit of the initial value by the addition of an aliquot of a $2 \mathrm{M}$ KOD solution. An even slower increase $(0.03$ units in two weeks) in $\mathrm{pD}$ was observed during deuterium exchange of glycine catalyzed by phenylglyoxylate in the presence of lowest concentrations of buffer. No new major signals were detected by ${ }^{1} \mathrm{H}$ NMR, and no significant deviation was observed in the kinetic plots of data for this reaction.

The exchange for deuterium of the first $\alpha-\mathrm{H}$ of glycine and of glycine methyl ester was followed by monitoring the disappearance of the singlet due to the $-\mathrm{CH}_{2}$ - group of the substrate and the appearance of the upfield-shifted triplet due to the -CHD- group by ${ }^{1} \mathrm{H}$ NMR spectroscopy at $500 \mathrm{MHz}$, as described in previous work. ${ }^{2}$ Reactions were monitored during the exchange for deuterium of $20-90 \%$ of the first $\alpha-\mathrm{H}$ of the substrate, and the reaction progress, $R$, was calculated using eq 3 , where $A_{\mathrm{CH} 2}$ and $A_{\mathrm{CHD}}$ are the integrated areas of the peaks for the $\alpha$ $\mathrm{CH}_{2}$ and the $\alpha$-CHD groups, respectively. Observed first-order rate constants for exchange for deuterium of a single proton of the $\alpha-\mathrm{CH}_{2}$ group of the substrate, $k_{\mathrm{obsd}}\left(\mathrm{s}^{-1}\right)$, were determined from the slopes of linear semilogarithmic plots of $R$ against time (eq 4 ). The values of the firstorder rate constant for exchange of the first $\alpha-\mathrm{CH}_{2}$ proton to give monodeuterated product, $k_{\mathrm{ex}}\left(\mathrm{s}^{-1}\right)$, were determined as $k_{\mathrm{ex}}=2 k_{\mathrm{obsd}}{ }^{2}$

$$
\begin{aligned}
& \mathrm{R}=\frac{A_{\mathrm{CH}_{2}}}{A_{\mathrm{CH}_{2}}+A_{\mathrm{CHD}}} \\
& \ln \mathrm{R}=-k_{\text {obsd }} t
\end{aligned}
$$

The rates of the deuterium exchange and hydrolysis reactions of glycine methyl ester in the presence of acetone are similar at pD 7.6. The deuterium enrichment of the glycine product of the hydrolysis reaction was determined by ${ }^{1} \mathrm{H}$ NMR analysis after more than 10 halftimes for the hydrolysis reaction. The values of $k_{\mathrm{ex}}=2 k_{\mathrm{obsd}}$ (Scheme 1) were determined from the integrated areas of the singlet due to the $\alpha-\mathrm{CH}_{2}$ group of glycine and the triplet due to the $\alpha$ CHD group of glycine using eq 5, where $k_{\text {hyd }}$ is the first-order rate constant for hydrolysis of glycine methyl ester under the conditions of the experiment. The values of $k_{\text {hyd }}$ were calculated

from eq 6 , where $f_{\mathrm{ND}_{3}^{+}}$is the fraction of substrate present in the reactive $\mathrm{N}$-protonated form, and using the second-order rate constants $\left(k_{\mathrm{B}}\right)_{\text {hyd }}$ for general base catalysis of the hydrolysis reaction (Table $\mathrm{S} 1$ of the Supporting Information) calculated from data reported in part in earlier work. ${ }^{2}$ A control experiment at pD 6.6 showed that there is no change in $k_{\text {hyd }}( \pm 5 \%)$, for reaction in the presence of a fixed concentration of phosphate buffer, as the concentration 
of acetone is increased from 0 to $0.2 \mathrm{M}$. This shows that there is no significant catalysis of the hydrolysis reaction of glycine methyl ester by acetone.

$$
\begin{gathered}
k_{\mathrm{ex}}=\frac{k_{\mathrm{hyd}}}{\left(\frac{A_{\mathrm{CH}_{2}}}{2 A_{\mathrm{CHD}}}-\frac{1}{2}\right)} \\
k_{\mathrm{hyd}}=\sum\left(\left(k_{\mathrm{B}}\right)_{\mathrm{hyd}}[B]\right) f_{\mathrm{ND}_{3}^{+}}
\end{gathered}
$$

\section{RESULTS}

\section{Equilibrium Constants for Imine Formation}

Figure $1(\cdot)$ shows the change with changing $\mathrm{pD}$ in $\left(\delta_{\mathrm{CH}_{2}}\right)_{\mathrm{obsd}}^{1}(\mathrm{ppm})$ of the signal for the $\alpha-$ $\mathrm{CH}_{2}$ group of 1/1-D (Scheme 2) that forms in $\mathrm{D}_{2} \mathrm{O}$ that initially contains $0.1 \mathrm{M}$ glycine methyl ester and $3 \mathrm{M}$ acetone at $25^{\circ} \mathrm{C}$ and $I=1.0(\mathrm{KCl})$. The signal for the $\alpha-\mathrm{CH}_{2}$ group moves from $4.18 \mathrm{ppm}$ at $\mathrm{pD} 8.8$ to $4.73 \mathrm{ppm}$ at $\mathrm{pD} 4.5$, because of protonation of the imino nitrogen. The solid line in Figure 1 shows the nonlinear least squares fit of the data to eq 7, derived for Scheme 2, where (a) $\delta_{\mathrm{CH}_{2}}^{\mathbf{1 - D}}=4.73$ and $\delta_{\mathrm{CH}_{2}}^{\mathbf{1}}=4.18 \mathrm{ppm}$ are the chemical shifts of the $\alpha-\mathrm{CH}_{2}$ group observed at extreme low and high $\mathrm{pD}$, and (b) $\left(K_{\mathrm{a}}\right)_{\mathbf{1}-\mathrm{D}}=10^{-7.3}$ is determined by treating this acidity constant as a variable parameter (Scheme 2).

Figure $1\left({ }^{\wedge}\right)$ also shows the change with changing $\mathrm{pD}$ in $\left(\delta_{\mathrm{CH}_{2}}\right)_{\mathrm{obsd}}^{2}(\mathrm{ppm})$ of the signal for the $\alpha-\mathrm{CH}_{2}$ group of $\mathbf{2} / \mathbf{2}-\mathbf{D} / \mathbf{2}-\mathrm{D}_{\mathbf{2}}$ (Scheme 3 ) that forms in $\mathrm{D}_{2} \mathrm{O}$ that initially contains glycine $(0.1$ $-2.0 \mathrm{M}$ depending upon the $\mathrm{pD}$ ) and $0.8 \mathrm{M}$ phenylglyoxylate at $25^{\circ} \mathrm{C}$ and $I=1.0(\mathrm{KCl}) .{ }^{28}$ The chemical shift of the $\alpha-\mathrm{CH}_{2}$ group changes because of protonation of the imine nitrogen and of the amino acid carboxylate groups. The solid line shows the fit of these data to eq 8 , derived for

Scheme 3, where $\delta_{\mathrm{CH}_{2}}^{2-\mathbf{D}_{2}}=4.51, \delta_{\mathrm{CH}_{2}}^{2-\mathbf{D}}=4.33$ and $\delta_{\mathrm{CH}_{2}}^{2}=4.11 \mathrm{ppm}$ are the ${ }^{1} \mathrm{H}$ NMR chemical shifts for the - $\mathrm{CH}_{2}$ - group of the different ionic forms of $\mathbf{2}$, and $\left(K_{\mathrm{a}}\right)_{\mathbf{2}}$ - $\mathbf{D}_{\mathbf{2}}$ and $\left(K_{\mathrm{a}}\right)_{\mathbf{2}}$-D are the acidity constants for 2-D $\mathbf{D}_{\mathbf{2}}$ and 2-D (Table 1) determined from the nonlinear least squares fit of the experimental data to eq 8 . There is a relatively large uncertainty in the value of $\left(K_{\mathrm{a}}\right)_{2}$ - $\mathbf{D}_{\mathbf{2}}$ because of the limited data for imine formation at low pD (Figure 2). Scheme 3 shows protonation of the glycine carboxylate of 2-D, for the sake of simplicity. However, there are insufficient data to distinguish this from protonation of the $\alpha$-imino carboxylate.

$$
\begin{gathered}
\left(\delta_{\mathrm{CH}_{2}}\right)_{\mathrm{obsd}}^{1}=\frac{\delta_{\mathrm{CH}_{2}}^{1}\left(K_{\mathrm{a}}\right)_{1-\mathrm{D}}+\delta_{\mathrm{CH}_{2}}^{1-\mathbf{D}} a_{\mathrm{D}}}{\left(\left(K_{\mathrm{a}}\right)_{1-\mathrm{D}}+a_{\mathrm{D}}\right)} \\
\left(\delta_{\mathrm{CH}_{2}}\right)_{\mathrm{obsd}}^{\mathbf{2}}=\frac{\delta_{\mathrm{CH}_{2}}^{2}\left(K_{\mathrm{a}}\right)_{2-\mathrm{D}}\left(K_{\mathrm{a}}\right)_{2-\mathrm{D}_{2}}+\delta_{\mathrm{CH}_{2}}^{2-\mathbf{D}_{2}}\left(K_{\mathrm{a}}\right)_{2-\mathrm{D}_{2}} a_{\mathrm{D}}+\delta_{\mathrm{CH}_{2}}^{2-\mathbf{D}_{2}} a_{\mathrm{D}}^{2}}{\left(\left(K_{\mathrm{a}}\right)_{2-\mathrm{D}}\left(K_{\mathrm{a}}\right)_{2-\mathbf{D}_{2}}+\left(K_{\mathrm{a}}\right)_{2-\mathrm{D}_{2}} a_{\mathrm{D}}+a_{D}^{2}\right)}
\end{gathered}
$$




$$
\left(K_{\mathrm{add}}\right)_{\mathrm{obsd}}=\left(K_{\mathrm{add}}\right)_{\mathrm{X}-\mathbf{D}}\left(\frac{a_{\mathrm{D}}+\left(K_{\mathrm{a}}\right)_{\mathbf{X}-\mathbf{D}}}{a_{\mathrm{D}}+\left(K_{\mathrm{a}}\right)_{\mathrm{GlyD}}}\right)
$$

The apparent equilibrium constants $\left(K_{\text {add }}\right)_{\text {obsd }}\left(\mathrm{M}^{-1}\right)$ for addition of glycine methyl ester to acetone, or for addition of glycine to phenylglyoxylate, to form the corresponding imines in $\mathrm{D}_{2} \mathrm{O}$ at $25^{\circ} \mathrm{C}$ were determined by ${ }^{1} \mathrm{H}$ NMR analysis as described in the Experimental section. Figure 2 shows the change, with changing $\mathrm{pD}$, in $\log \left(K_{\mathrm{add}}\right)_{\text {obsd }}$ for addition of glycine methyl ester to acetone $(\boldsymbol{\Delta})$ or of glycine to phenylglyoxylate $\left({ }^{\wedge}\right)$. The line through the triangles shows the fit of data for the first reaction to eq $9(\mathbf{X}=\mathbf{1})$, derived for Scheme 2, using $\left(K_{\mathrm{a}}\right)_{\mathrm{MeOGlyD}}$ $=3.3 \times 10^{-9} \mathrm{M},{ }^{1}\left(K_{\mathrm{a}}\right)_{\mathbf{1}-\mathbf{D}}=5.0 \times 10^{-8} \mathrm{M}($ Table 1$)$ and $\left(K_{\text {add }}\right) \mathbf{1 - D}=0.0033 \mathrm{M}^{-1}$ determined for the formation of the iminium ion at low $\mathrm{pD}$. The line through the circles in Figure 2 shows the fit of data for the second reaction to eq $9(\mathbf{X}=2)$, derived for Scheme 3, using $\left(K_{\mathrm{a}}\right)_{\mathrm{GlyD}}=$ $4.5 \times 10^{-11} \mathrm{M},{ }^{1}\left(K_{\mathrm{a}}\right)_{2-\mathrm{D}}=6.5 \times 10^{-7} \mathrm{M}$ (Table 1$)$ and values of $\left(K_{\mathrm{add}}\right) 2=1.50 \mathrm{M}^{-1}$ and $\left(K_{\text {add }}\right)_{2-\mathrm{D}}=(1.0 \pm 0.1) \times 10^{-4} \mathrm{M}^{-1}$ determined for the reaction at low and high $\mathrm{pD}$, respectively. Figure $2(\cdot)$ also shows values of $\left(K_{\text {add }}\right)_{\text {obsd }}$ for addition of glycine to $5^{\prime}$-deoxypyridoxal determined in earlier work. ${ }^{15}$

\section{Rate Constants for Deuterium Exchange}

(1) Catalysis by Acetone-The exchange for deuterium of the first $\alpha$-proton of the methylene group of glycine methyl ester in $\mathrm{D}_{2} \mathrm{O}$ at $25^{\circ} \mathrm{C}$ and $I=1.0(\mathrm{KCl})$ was followed by ${ }^{1} \mathrm{H}$ NMR (500 MHz) as described in previous work. ${ }^{1,4}$ Figure $3 \mathrm{~A}$ shows the linear dependence of $k_{\mathrm{ex}}=2 k_{\text {obsd }}$ (Scheme 1) on the total concentration of acetate buffer (pD 5.56) for reactions in the presence of increasing [acetone]. The intercepts of these correlations are equal to $k_{\mathrm{o}}=k_{\mathrm{w}} f_{\mathbf{1}-\mathrm{D}}\left(\mathrm{s}^{-1}\right.$, Table 2$)$ for deuterium exchange catalyzed by the solvent, where $f_{\mathbf{1}-\mathbf{D}}$ is the fraction of glycine methyl ester present as the iminium ion adduct 1-D (eq 10, $\mathbf{X}$ $=\mathbf{1}$, derived for Scheme 2$)^{29}$ and $k_{\mathrm{w}}$ is the apparent first order rate constant for the solvent reaction.

The plot of $k_{\mathrm{O}}\left(\mathrm{s}^{-1}\right.$, Table 2) against [acetone] shown in Figure 3B is linear. The slope is equal to the apparent rate constant $\left(k_{\mathrm{w}}\right)_{\mathrm{obsd}}=2.7 \times 10^{-8} \mathrm{M}^{-1} \mathrm{~s}^{-1}$ for acetone-catalyzed deprotonation of glycine methyl ester by solvent at pD 5.56 (eq 11). Eq 12, which can be simply derived from eq 10 and 11, shows the relationship between $\left(k_{\mathrm{w}}\right)_{\mathrm{obsd}}$ and $k_{\mathrm{w}}$ for deprotonation of 1-D by the solvent $\mathrm{D}_{2} \mathrm{O}$. Substitution of $\left(k_{\mathrm{w}}\right)_{\mathrm{obsd}}=2.7 \times 10^{-8} \mathrm{M}^{-1} \mathrm{~s}^{-1},\left(K_{\mathrm{add}}\right)_{1-\mathrm{D}}=0.0033 \mathrm{M}^{-1}$,

$\left(K_{\mathrm{a}}\right)_{\mathrm{Gly}-\mathrm{D}}=3.3 \times 10^{-9} \mathrm{M}$ and $a_{\mathrm{D}}=10^{-5.56} \mathrm{M}$ into eq 12 gives $k_{\mathrm{w}}=8.2 \times 10^{-6} \mathrm{~s}^{-1}$. The same analysis of data for reactions in phosphate buffers at $\mathrm{pD} 7.64$ and 6.61 (Table 2) gives $k_{\mathrm{w}}=9.3$ $\times 10^{-4} \mathrm{~s}^{-1}$ and $k_{\mathrm{w}}=1.0 \times 10^{-4} \mathrm{~s}^{-1}$, respectively. Figure $4\left(^{\wedge}\right)$ shows the pD-rate profile of $\log$ for deprotonation of 1-D in $\mathrm{D}_{2} \mathrm{O}$. The solid line of unit slope shows that deprotonation of 1$\mathbf{D}$ is by $\mathrm{DO}^{-}\left(\left(k_{\mathrm{DO}}\right)_{1-\mathbf{D}}\right.$, Scheme 2$)$. The nonlinear least squares fit of the data to eq 13 , where $K_{\mathrm{w}}=10^{-14.87} \mathrm{M}^{2}$ is the ion product of $\mathrm{D}_{2} \mathrm{O}$ at $25^{\circ} \mathrm{C}$ and $\gamma_{\mathrm{OL}}=0.79$ is the apparent activity coefficient of $\mathrm{DO}^{-}$under our experimental conditions, gives $\left(k_{\mathrm{DO}}\right)_{\mathbf{1}-\mathrm{D}}=13,000 \mathrm{M}^{-1} \mathrm{~s}^{-1}$ for deprotonation of 1-D by $\mathrm{DO}^{-}$(Scheme 2$)^{2}$

$$
\begin{gathered}
f_{\mathbf{X}-\mathbf{D}}=\frac{\left(K_{\text {add }}\right)_{\mathbf{X}-\mathbf{D}}[\text { Ketone }]}{\left(1+\frac{\left(K_{\mathrm{a}}\right)_{\text {Gly }-\mathrm{D}}}{a_{\mathrm{D}}}\right)} \\
k_{\mathrm{O}}=\left(k_{\mathrm{w}}\right)_{\text {obsd }}[\text { Ketone }]=k_{\mathrm{w}} f_{\mathbf{X}-\mathbf{D}}
\end{gathered}
$$




$$
\begin{gathered}
k_{\mathrm{w}}=\frac{\left(k_{\mathrm{W}}\right)_{\mathrm{obsd}}\left(1+\frac{\left(K_{\mathrm{a}}\right)_{\mathrm{Gly}-\mathrm{D}}}{a_{\mathrm{D}}}\right)}{\left(K_{\mathrm{add}}\right)_{\mathrm{x}-\mathbf{D}}} \\
\log k_{\mathrm{w}}=\log \left(\frac{\left(k_{\mathrm{DO}}\right)_{1-\mathrm{D}} K_{\mathrm{W}}}{\gamma_{\mathrm{OL}}}\right)+\mathrm{pD}
\end{gathered}
$$

The slopes of the correlations in Figure $3 \mathrm{~A}$ are equal to $\left(k_{\mathrm{B}}\right)_{\mathrm{obsd}}=\left(k_{\mathrm{B}}\right)_{1-\mathrm{D}} f_{\mathrm{B}} f_{\mathbf{1}-\mathrm{D}}$ (Table 2) for the deuterium exchange reaction catalyzed by buffer at the given concentration of acetone, where $\left(k_{\mathrm{B}}\right)_{1-\mathrm{D}}\left(\mathrm{M}^{-1} \mathrm{~S}^{-1}\right)$ is the second-order rate constant for deprotonation of 1-D by the buffer base and $f_{\mathrm{B}}$ is the fraction of the catalyst in the basic form. The values of $\left(k_{\mathrm{B}}\right)_{\text {obsd }}$ increase linearly with [acetone], as shown in Figure 3C. The slope of this correlation is the apparent third-order rate constant for deprotonation of glycine methyl ester catalyzed by acetone and acetate anion, $\left(k_{\mathrm{B}}^{\mathrm{T}}\right)_{\mathrm{obsd}}=1.6 \times 10^{-6} \mathrm{M}^{-2} \mathrm{~s}^{-1}$ (Table 2). Substitution of $\left(k_{\mathrm{B}}^{\mathrm{T}}\right)_{\text {obsd }}$ into eq 14 along with $\left(K_{\mathrm{add}}\right)_{1-\mathrm{D}}=0.0033 \mathrm{M}^{-1}, f_{\mathrm{B}}=0.75,\left(K_{\mathrm{a}}\right)_{\mathrm{Gly}-\mathrm{D}}=3.3 \times 10^{-9} \mathrm{M}$ and $a_{\mathrm{D}}=10^{-5.56} \mathrm{M}$ gives $\left(k_{\mathrm{B}}\right)_{1-\mathrm{D}}=6.5 \times 10^{-4} \mathrm{M}^{-1} \mathrm{~s}^{-1}$ for deprotonation of $\mathbf{1 - D}$ by acetate ion (Scheme 2 ).

$$
\left(k_{\mathrm{B}}\right)_{1-\mathrm{D}}=\frac{\left(k_{\mathrm{B}}^{\mathrm{T}}\right)_{\mathrm{obsd}}\left(1+\frac{\left(K_{\mathrm{a}}\right)_{\mathrm{Gly}-\mathrm{D}}}{a_{\mathrm{D}}}\right)}{f_{\mathrm{B}}\left(K_{\mathrm{add}}\right)_{1-\mathrm{D}}}
$$

A similar treatment of the data for the reactions catalyzed by phosphate buffers at pD 7.64 and 6.61 (Table 2) gives the values $\left(k_{\mathrm{B}}^{\mathrm{T}}\right)_{\text {obsd }}$ reported in Table 2. Substitution of these values of $\left(k_{\mathrm{B}}^{\mathrm{T}}\right)_{\text {obsd }}$ into eq 14 , as described above for the reactions catalyzed by acetate ion, gives values of $\left(k_{\mathrm{B}}\right)_{1-\mathrm{D}}=4.7 \times 10^{-2}$ and $4.8 \times 10^{-2} \mathrm{M}^{-1} \mathrm{~s}^{-1}$ for reactions at $\mathrm{pD} 7.64$ and 6.61, respectively, for deprotonation of 1-D by phosphate dianion.

Values of $k_{\mathrm{ex}}\left(\mathrm{s}^{-1}\right)$ for the exchange for deuterium of the first $\alpha$-proton of glycine methyl ester at pD 7.64 (0.1 M phosphate buffer) in the presence of acetone and quinuclidine, 3quinuclidinol or 3-chloroquinuclidine are reported in Table S2 of the Supporting Information. Table 3 reports values of $\left(k_{\mathrm{B}}\right)_{\text {obsd }}\left(\mathrm{M}^{-1} \mathrm{~s}^{-1}\right)$ for catalysis by these tertiary amines of deuterium exchange into glycine methyl ester that were determined from the slopes of linear plots (not shown) of $k_{\mathrm{ex}}$ against the total concentration of the acidic and basic forms of the amine. Values of $\left(k_{\mathrm{B}}\right)_{1-\mathrm{D}}\left(\mathrm{M}^{-1} \mathrm{~s}^{-1}\right)$ (Table 3$)$ were calculated from the values of $\left(k_{\mathrm{B}}\right)_{\text {obsd }}$ as described above for the acetate anion-catalyzed reaction.

(2) Catalysis by Phenylglyoxylate-The exchange for deuterium of the first $\alpha$-proton of glycine was studied in $\mathrm{D}_{2} \mathrm{O}$ at $25{ }^{\circ} \mathrm{C}$ and $I=1.0(\mathrm{KCl})$ in solutions buffered with potassium phosphate (pD 6.49-7.65). Table S3 of the Supporting Information gives the observed firstorder rate constants $k_{\mathrm{ex}}\left(\mathrm{s}^{-1}\right)$ for deuterium exchange in the presence of various concentrations of phenylglyoxylate and phosphate buffer at pD 6.49, 7.05 and 7.65, determined as described in the Experimental Section. Figure 5 shows the effect of increasing concentrations of phosphate buffer at $\mathrm{pD} 7.65$ on $k_{\mathrm{ex}}\left(\mathrm{s}^{-1}\right)$ for reactions at different fixed concentrations of phenylglyoxylate. The intercepts of these linear plots are the first-order rate constants $k_{\mathrm{O}}=$ $k_{\mathrm{W}} f_{2-\mathrm{D}}\left(\mathrm{s}^{-1}\right.$, Table 4$)$ for solvent-catalyzed exchange at $\mathrm{pD} 7.65$, where $f_{2-\mathrm{D}}=$ $\left(K_{\mathrm{add}}\right)_{2-\mathrm{D}}[$ phenylglyoxylate] is the fraction of glycine present as 2-D calculated using eq 10 $\left[\mathbf{X}=\mathbf{2}, 1 \gg\left(\left(K_{\mathrm{a}}\right)_{\mathrm{Gly}-\mathrm{D}} / a_{\mathrm{D}}\right)\right]$. Table 4 reports values of $k_{\mathrm{W}}$, calculated using eq 15 , for reactions 
at different constant [phenylglyoxylate]. Less data is reported for reactions pD 7.05 and $\mathrm{pD}$ 6.49 , because the slow deuterium exchange reactions could only be detected at high [phenylglyoxylate]. The linear plot (not shown) of $k_{\mathrm{W}}\left(\mathrm{s}^{-1}\right)$ against [DO $]$ was fit to eq 16 to give $\left(k_{\mathrm{DO}}\right)_{2-\mathrm{D}}=1.7 \times 10^{4} \mathrm{M}^{-1} \mathrm{~s}^{-1}$ for deprotonation of 2-D by DO ${ }^{-}\left(\right.$Scheme 3 and $\left(k_{\mathrm{w}}\right)_{\mathrm{o}}=$ $3.1 \times 10^{-4} \mathrm{~s}^{-1}$ for either $\mathrm{pD}$-independent deprotonation of 2-D or the kinetically equivalent deprotonation of $\mathbf{2}-\mathbf{D}_{\mathbf{2}}$ by $\mathrm{DO}^{-}$(see Discussion section).

$$
k_{\mathrm{W}}=k_{\mathrm{o}} / f_{2-\mathbf{D}}
$$

$$
k_{\mathrm{w}}=\left(k_{\mathrm{w}}\right)_{\mathrm{O}}+\left(k_{\mathrm{DO}}\right)_{2-\mathrm{D}}\left[\mathrm{DO}^{-}\right]
$$

The slopes of the linear correlations in Figure 5 are apparent second-order rate constants, $\left(k_{\mathrm{B}}\right)_{\text {obsd }}=k_{\mathrm{B}} f_{\mathrm{B}} f_{2-\mathrm{D}}\left(\mathrm{M}^{-1} \mathrm{~s}^{-1}\right)$ for buffer-catalyzed deprotonation of glycine, where $k_{\mathrm{B}}$ is the second-order rate constant for deprotonation of 2-D by $\mathrm{DPO}_{4}{ }^{2-}$ (Scheme 3 ) and $f_{\mathrm{B}}$ is the fraction of the buffer in the basic form (Table 4). The values for $k_{\mathrm{B}}$ reported in Table 4 were calculated from $\left(k_{\mathrm{B}}\right)_{\text {obsd }}$ using the appropriate values of $f_{\mathrm{B}}$ calculated from the $\mathrm{pD}$ and $\mathrm{p} K_{\mathrm{a}}$ of the buffer catalyst, and $f_{\text {2-D }}=\left(K_{\text {add }}\right)_{2-D}$ [phenylglyoxylate] (see above). The second-order rate constants determined for deprotonation of 2-D are also summarized in Table 5.

\section{DISCUSSION}

The exchange of the $\alpha-\mathrm{CH}_{2}$ hydrogen of glycine methyl ester for deuterium from $\mathrm{D}_{2} \mathrm{O}$ catalyzed by acetone was monitored at $25^{\circ} \mathrm{C}$ and neutral $\mathrm{pD}$, as described in earlier work. ${ }^{1,4}$ There is no detectable $(<1 \%)$ catalysis by acetone of the deuterium exchange of the $\alpha-\mathrm{CH}_{2}$ hydrogen of glycine after 1-month incubation of acetone $(1 \mathrm{M})$ with glycine in $\mathrm{D}_{2} \mathrm{O}$ at $\mathrm{pD} 7.8$ and $25^{\circ}$ C. Experiments to characterize catalysis of the deuterium exchange of the $\alpha-\mathrm{CH}_{2}$ hydrogen of glycine by pyruvate, an analog for the pyruvoyl prosthetic group used in some enzymecatalyzed decarboxylation reactions, ${ }^{17,18,20}$ failed because of the competing bimolecular aldol condensation reaction of pyruvate. Phenylglyoxylate was examined as a model for pyruvate that lacks acidic $\alpha$-hydrogen atoms.

\section{Reaction Pathways}

The kinetic data for acetone-catalyzed deuterium exchange reactions of glycine methyl ester was fit to a mechanism in which the imine 1-D undergoes irreversible deprotonation by $\mathrm{DO}^{-}$, the conjugate base of solvent, and by other Brønsted bases. Two pathways are observed for deprotonation of 2-D by solvent and buffer bases. The dominant pathway at $\mathrm{pD} 7.65$ is for deprotonation of 2-D by $\mathrm{DO}^{-}$and phosphate dianion. The apparent rate constant for the "solvent" reaction approaches a limiting value of $k_{\mathrm{w}}=3.1 \times 10^{-4} \mathrm{~s}^{-1}$ and the apparent rate constant for the buffer catalyzed rate constant increases as the $\mathrm{pD}$ is decreased to 6.49 (Table 4). These observations show that additional pathways are important for the reactions of these bases with 2 at low $\mathrm{pD}$.

Figure 4 ( 4 ) shows a logarithmic pD-rate profile of rate constants $k_{\mathrm{w}}$ for deprotonation of 2D. The solid line shows the fit of the data obtained using values of $\left(k_{\mathrm{DO}}\right)_{\mathbf{2}-\mathbf{D}}=1.7 \times 10^{4}$ $\mathrm{M}^{-1} \mathrm{~s}^{-1}$ and $\left(k_{\mathrm{w}}\right)_{\mathrm{o}}=3.1 \times 10^{-4} \mathrm{~s}^{-1}$ for the $\mathrm{DO}^{-}$-catalyzed and the $\mathrm{pD}$-independent reactions, respectively. No similar upward breaks at $\mathrm{pD} 5-7$ are observed in the $\mathrm{pD}$-rate profiles for deprotonation of simpler amino acid derivatives. ${ }^{1,30}$ This suggests that $\mathrm{DO}^{-}$is normally so much more reactive than DOD toward deprotonation of $\alpha$-amino carbon that the reaction remains first order in $\left[\mathrm{DO}^{-}\right]$at $\mathrm{pD} 5-7$. We therefore suggest that the new pathway observed 
at low $\mathrm{pD}$ is for deprotonation of a second ionic form or the substrate $\left(\mathbf{2}-\mathbf{D}_{\mathbf{2}}\right)$ by $\mathrm{DO}^{-}\left(\mathrm{Scheme}^{-}\right.$ 3 ). The observed rate constant for this reaction is $\mathrm{pD}$-independent at $\mathrm{pD}>\mathrm{p}\left(K_{\mathrm{a}}\right)_{\mathbf{2}-\mathbf{D}_{2}}$ (Table 1$)$ because the decrease in $\mathrm{DO}^{-}$at decreasing $\mathrm{pD}$ is balanced by the increase in the concentration of the strong carbon acid 2-D . Eq. 17 gives the relationship between the apparent pDindependent rate constant $\left(k_{\mathrm{w}}\right)_{\mathrm{O}}$ and $\left(k_{\mathrm{DO}}\right)_{\mathbf{2}-\mathbf{D}_{2}}$ for the deprotonation of the minor ionic form $\mathbf{2}-\mathbf{D}_{2}$ by deuterioxide ion. A value of $\left(k_{\mathrm{DO}}\right)_{2}$ - $\mathbf{D}_{\mathbf{2}} \approx 3 \times 10^{8} \mathrm{M}^{-1} \mathrm{~s}^{-1}$ (Table 5) was calculated using eq 17 , the experimental value for $\left(k_{\mathrm{w}}\right)_{\mathrm{O}}, K_{\mathrm{w}}=10^{-14.87} \mathrm{M}^{2}, \gamma_{\mathrm{OL}}=0.78$ and $\left(K_{\mathbf{a}}\right)_{\mathbf{2}-\mathbf{D}_{\mathbf{2}}} \approx$ $1.7 \times 10^{-3} \mathrm{M}($ Table 1$)$.

$$
\begin{gathered}
\left(k_{\mathrm{W}}\right)_{\mathrm{O}}=\frac{\left(k_{\mathrm{DO}}\right)_{2-\mathbf{D}_{2}} K_{\mathrm{W}}}{\left(K_{\mathrm{a}}\right)_{2-\mathbf{D}_{2}} \gamma_{\mathrm{OL}}} \\
k_{\mathrm{B}}=\left(k_{\mathrm{B}}\right)_{2-\mathrm{D}}+\frac{\left(k_{\mathrm{B}}\right)_{2-\mathbf{D}_{2}}}{\left(K_{\mathrm{a}}\right)_{2-\mathbf{D}_{2}}} a_{\mathrm{D}}
\end{gathered}
$$

The increase with decreasing $\mathrm{pD}$ in the apparent second-order rate constant $k_{\mathrm{B}}$ for deprotonation of 2-D by $\mathrm{DPO}_{4}{ }^{2-}$ is also due to the appearance of a second reaction pathway for deprotonation of the strong carbon acid 2-D $\mathbf{D}_{\mathbf{2}}$ by $\mathrm{DPO}_{4}{ }^{2-}$ (Scheme 3). Eq. 18 gives the relationship between the apparent rate constants $k_{\mathrm{B}}$ and the rate constants for deprotonation of 2-D $\left(\left(k_{\mathrm{B}}\right)_{2-\mathrm{D}}\right)$ and 2-D $\mathbf{D}_{2}\left(\left(k_{\mathrm{B}}\right)_{2-\mathbf{D}_{2}}\right)$ by $\mathrm{DPO}_{4}{ }^{2-}$. The plot (not shown) of $k_{\mathrm{B}}\left(\mathrm{M}^{-1} \mathrm{~s}^{-1}\right)$ against is $a_{\mathrm{D}}$ linear. The intercept of this plot gives the second-order rate constant for deprotonation of the iminium ion 2-D by $\mathrm{DPO}_{4}{ }^{2-},\left(k_{\mathrm{B}}\right)_{\mathbf{2}-\mathrm{D}}=2.8 \times 10^{-2} \mathrm{M}^{-1} \mathrm{~s}^{-1}$ (Table 5). Combining the slope of this plot with $\left(K_{\mathbf{a}}\right)_{2-D_{2}}=1.7 \times 10^{-3} \mathrm{M}$ (Table 1$)$ gives the second-order rate constant for deprotonation of $\mathbf{2}-\mathbf{D}_{\mathbf{2}}$ by $\mathrm{DPO}_{4}{ }^{2-},\left(k_{\mathrm{B}}\right)_{\mathbf{2}-\mathbf{D}_{\mathbf{2}}}=1 \times 10^{2} \mathrm{M}^{-1} \mathrm{~s}^{-1}$ (Table 5). There is a very large uncertainty in the values of the rate constants estimated for deprotonation of $\mathbf{2}-\mathbf{D}_{\mathbf{2}}$ by $\mathrm{DO}^{-}$and by $\mathrm{DPO}_{4}{ }^{2-}$. First, there is the inherent uncertainty in the value for $\left(K_{\mathrm{a}}\right)_{\mathbf{2}-\mathbf{D}_{2}}$ determined by fitting experimental data from Figure 1 to Scheme 3. Second, there are two carboxylates at 2D of uncertain relative basicity which may undergo protonation and our limited experimental data is not sufficient to distinguish between the two different forms of $\mathbf{2}-\mathbf{D}_{\mathbf{2}}$.

\section{Brønsted Correlations}

The Brønsted correlation of second-order rate constants $k_{\mathrm{B}}\left(\mathrm{M}^{-1} \mathrm{~s}^{-1}\right)$ for deprotonation of 1$\mathbf{D}\left({ }^{\wedge}\right)$ shown in Figure 6 was obtained using data from Table 5. The slope of this correlation, $\beta=0.83 \pm 0.01$, is smaller than the value of $\beta=0.92 \pm 0.04$ for deprotonation of $N$-protonated glycine methyl ester ( $\mathbf{\wedge}$ ) determined in earlier work. ${ }^{1}$ The smaller Brønsted $\beta$ observed for 1D compared with N-protonated glycine methyl ester is consistent with a Hammond type shift to an earlier transition state for deprotonation of the more strongly acidic carbon acid. 31

\section{Electrophilic Catalysis of Deprotonation of Glycine}

A broad goal of this work is to determine the effect of different electrophilic catalysts on the carbon acidity of glycine. Chart 2 shows that formation of an imine between acetone and glycine methyl ester causes a healthy 2,200-fold increase in the second order rate constant $k_{\mathrm{DO}}$ for deprotonation of the $\alpha$-amino carbon by deuterioxide ion. This reflects the $\mathrm{ca} 7$ unit lower acid $\mathrm{p} K_{\mathrm{a}}$ of the more reactive carbon acid. ${ }^{2}$ The formation of the imine between glycine and phenylglyoxylate causes a much larger $2.2 \times 10^{8}$-fold increase in the second-order rate constant $k_{\mathrm{DO}}$ for deprotonation of the $\alpha$-amino carbon by deuterioxide ion. This is 50 -fold 
larger than the effect of formation of an imine to the oxygen-ionized form of 5'-deoxypyridoxal (Chart 2).

Combining $k_{\mathrm{DO}}=2 \times 10^{4} \mathrm{M}^{-1} \mathrm{~s}^{-1}$ for deprotonation of $2-\mathrm{D}$ with an estimated solvent deuterium isotope effect of $k_{\mathrm{DO}} / k_{\mathrm{HO}}=1.5^{32}$ gives $k_{\mathrm{HO}}=2.7 \times 10^{4} \mathrm{M}^{-1} \mathrm{~s}^{-1}$ for deprotonation of $\mathbf{2}-\mathbf{H}$ by hydroxide ion in $\mathrm{H}_{2} \mathrm{O}$ (Scheme 3). Eq 19 is the linear logarithmic correlation between $k_{\mathrm{HO}}$ and the carbon acidity $\mathrm{p} K_{\mathrm{CH}}$ for deprotonation of cationic ketones and esters. ${ }^{2}$ This correlation and $k_{\mathrm{HO}}=2.7 \times 10^{4} \mathrm{M}^{-1} \mathrm{~s}^{-1}$ gives a value of $\mathrm{p} K_{\mathrm{a}}=13$ for the carbon acidity of $\mathbf{2}-\mathbf{H}$. The carbon acid $\mathrm{p} K_{\mathrm{a}}$ for this iminium ion is 16 units smaller than $\mathrm{p} K_{\mathrm{a}}$ of 29 for the parent carbon acid glycine, ${ }^{1}$ and smaller even than the $\mathrm{p} K_{\mathrm{a}}$ of 17 estimated for $3-\mathbf{H}_{2} \cdot{ }^{15}$ By comparison, formation of an imine to acetone causes only a 7 unit reduction in the $\mathrm{p} K_{\mathrm{a}}$ of glycine methyl ester. ${ }^{2}$ The strong carbon acidity for $\mathbf{2}-\mathbf{H}$ shows the extensive stabilization of negative charge of the carbanion 4, that is presumably due to delocalization of negative charge onto the electrondeficient substituents at 4 .

It is important to distinguish between the effects of formation of iminium ions on the kinetic carbon acidity shown in Chart 2, and the overall reactivity of the ketones as catalysts of deprotonation of glycine methyl ester and glycine. In particular, 5'-deoxypyridoxal (DPL) is a much better catalyst of deprotonation of glycine than is phenylglyoxylate anion, despite the weaker carbon acidity of the adduct to glycine (Chart 2). Chart 3 shows a comparison of the rate constants for solvent-catalyzed deprotonation of glycine methyl ester and glycine, and the rate constants observed upon addition of a $0.01 \mathrm{M}$ ketone catalyst. The first row shows that, despite the strong carbon acidity of the iminium ion adduct, $0.010 \mathrm{M}$ acetone provides only modest catalysis of deprotonation of glycine methyl ester at pD 7.6, because of the unfavourable equilibrium constant for imine formation. A 250-fold rate acceleration is observed for catalysis of deprotonation of glycine by $0.010 \mathrm{M}$ of the much more effective catalyst phenylglyoxylate. However, this rate acceleration pales in comparison to the 3,000,000-fold acceleration observed for catalysis of deprotonation of glycine by $0.010 \mathrm{M} \mathrm{DPL}$ at $\mathrm{pH} 7.1$, where the estimated rate constant for solvent-catalyzed deprotonation of glycine is only $5 \times 10^{-12} \mathrm{~s}^{-1.1}$

The large difference in the observed catalytic activity of DPL and phenylglyoxylate is almost entirely due to the more favourable equilibrium constant for formation of the imine to the former electrophile (Figure 2). The imine 2-D is only barely detectable by ${ }^{1} \mathrm{H}-\mathrm{NMR}$ in solutions that contain molar concentrations of glycine and $0.80 \mathrm{M}$ phenylglyoxylate anion, while the reaction of $0.10 \mathrm{M}$ glycine with $0.010 \mathrm{M} \mathrm{DPL}$ at $\mathrm{pH} 7.1$ results in conversion of $80 \%$ of the cofactor to $\mathbf{3}-\mathbf{H}_{2}$ at chemical equilbrium. ${ }^{15}$ These data show that one imperative for the strong preference of enzyme catalysts to use pyridoxal 5'-phosphate rather than the pyruvoyl prosthetic group $17,18,20$ as a coenzyme for catalysis of the reactions of amino acids is the larger affinity of the pyridine cofactor compared with $\alpha$-keto acids for addition to the amino group to form an imine. This imperative was noted in an earlier study of imine formation to PLP. 33

We conclude that imines between pyridoxal and amino acids are strongly stabilized by intramolecular interaction between the pyridine ring, the ring substitutents and the imino nitrogen, ${ }^{33}$ compared to the corresponding intramolecular interactions at imines between amino acids and simple ketones and aldehydes. There is an extensive literature on imine formation in water. However, to the best of our knowledge there has been no systematic study reported to rationalize the high stability of imines to PLP compared to imines to simple aldehydes and ketones. These experiments are currently in progress in the laboratory at the Universidad de Santiago. 


\section{Supplementary Material}

Refer to Web version on PubMed Central for supplementary material.

\section{Acknowledgments}

We acknowledge the National Institutes of Health (Grant GM 39754 to J. P. R.), and the Ministerio de Educación y Ciencia and the European Regional Development Fund (ERDF) (Grant CTQ2004-06594 to A. R. and J. C.) for generous support of this work.

\section{References}

1. Rios A, Amyes TL, Richard JP. J Am Chem Soc 2000;122:9373-9385.

2. Rios A, Crugeiras J, Amyes TL, Richard JP. J Am Chem Soc 2001;123:7949-7950. [PubMed: 11493086]

3. Rios A, Richard JP. J Am Chem Soc 1997;119:8375-8376.

4. Rios A, Richard JP, Amyes TL. J Am Chem Soc 2002;124:8251-8259. [PubMed: 12105903]

5. Richard JP, Amyes TL. Bioorg Chem 2004;32:354-366. [PubMed: 15381401]

6. Spies MA, Toney MD. Biochemistry 2003;42:5099-5107. [PubMed: 12718553]

7. Spies MA, Woodward JJ, Watnik MR, Toney MD. J Am Chem Soc 2004;126:7464-7475. [PubMed: 15198593]

8. Gallo KA, Tanner ME, Knowles JR. Biochemistry 1993;32:3991-3997. [PubMed: 8097109]

9. Glavas S, Tanner ME. Biochemistry 1999;38:4106-4113. [PubMed: 10194325]

10. Puig E, Garcia-Viloca M, Gonzalez-Lafont A, Lluch JM. J Phys Chem A 2006;110:717-725. [PubMed: 16405345]

11. Pillai B, Cherney MM, Diaper CM, Sutherland A, Blanchard JS, Vederas JC, James MNG. Proc Nat Acad Sci, (USA) 2006;103:8668-8673. [PubMed: 16723397]

12. Patrick JS, Yang SS, Cooks RG. J Am Chem Soc 1966;118:231-232.

13. Price WD, Jockusch RA, Williams ER. J Am Chem Soc 1998;120:3474-3484. [PubMed: 16543945]

14. Dixon JE, Bruice TC. Biochemistry 1973;12:4762-4766. [PubMed: 4773854]

15. Toth K, Richard JP. J Am Chem Soc 2007;129:3013-3021. [PubMed: 17298067]

16. Toney MD. Arch Biochem Biophys 2005;433:279-287. [PubMed: 15581583]

17. Tolbert WD, Zhang Y, Cottet SE, Bennett EM, Ekstrom JL, Pegg AE, Ealick SE. Biochemistry 2003;42:2386-2395. [PubMed: 12600205]

18. Graham DE, Xu H, White RH. J Biol Chem 2002;277:23500-23507. [PubMed: 11980912]

19. Bach RD, Canepa C. J Am Chem Soc 1997;119:11725-11733.

20. Gallagher T, Rozwarski DA, Ernst SR, Hackert ML. J Mol Biol 1993;230:516-528. [PubMed: 8464063]

21. Owen TC, Young PR Jr. FEBS Letters 1974;43:308-312. [PubMed: 4415413]

22. Young PR, Howell LG, Owen TC. J Am Chem Soc 1975;97:6544-6551. [PubMed: 1184869]

23. Glasoe PK, Long FA. J Phys Chem 1960;64:188-190.

24. Amyes TL, Richard JP. J Am Chem Soc 1996;118:3129-3141.

25. Rios A, O’Donoghue AC, Amyes TL, Richard JP. Can J Chem 2005;83:1536-1542.

26. Richard JP, Williams G, Gao J. J Am Chem Soc 1999;121:715-726.

27. Williams G, Maziarz EP, Amyes TL, Wood TD, Richard JP. Biochemistry 2003;42:8354-8361. [PubMed: 12846584]

28. There is little hydration of the carbonyl group of phenylglyoxalate $(\ll 1 \%)$ because only $5 \%$ of pyruvate anion is hydrated in water [ Esposito A, Lukas A, Meany JE, Pocker Y. Can J Chem 1999;77:1108-1117.1117] and the phenyl for methyl group substitution at pyuvate is expected to cause the same ca 130 fold decrease in the equilibrium constant for hydration observed for acetaldehyde [ Guthrie JP. J Am Chem Soc 2000;122:5529-5538.5538] 
29. Derived assuming that the concentration of imine/iminium ion is negligible because less than $1 \%$ of the amino acid is converted to the imine/iminium ion adduct in the presence of $0.5 \mathrm{M}$ acetone at $\mathrm{pD}$ $<8$.

30. Richard JP, Williams G, O’Donoghue AC, Amyes TL. J Am Chem Soc 2002;124:2957-2968. [PubMed: 11902887]

31. Hammond GS. J Am Chem Soc 1955;77:334-338.

32. This is the secondary solvent deuterium isotope effect determined for deprotonation of acetone by hydroxide ion at $25^{\circ} \mathrm{C}$ [ Pocker Y. Chem Ind 1959:1383-1384.1384]

33. Gout E, Zador M, Beguin CG. Nov J Chim 1984;8:243-250. 


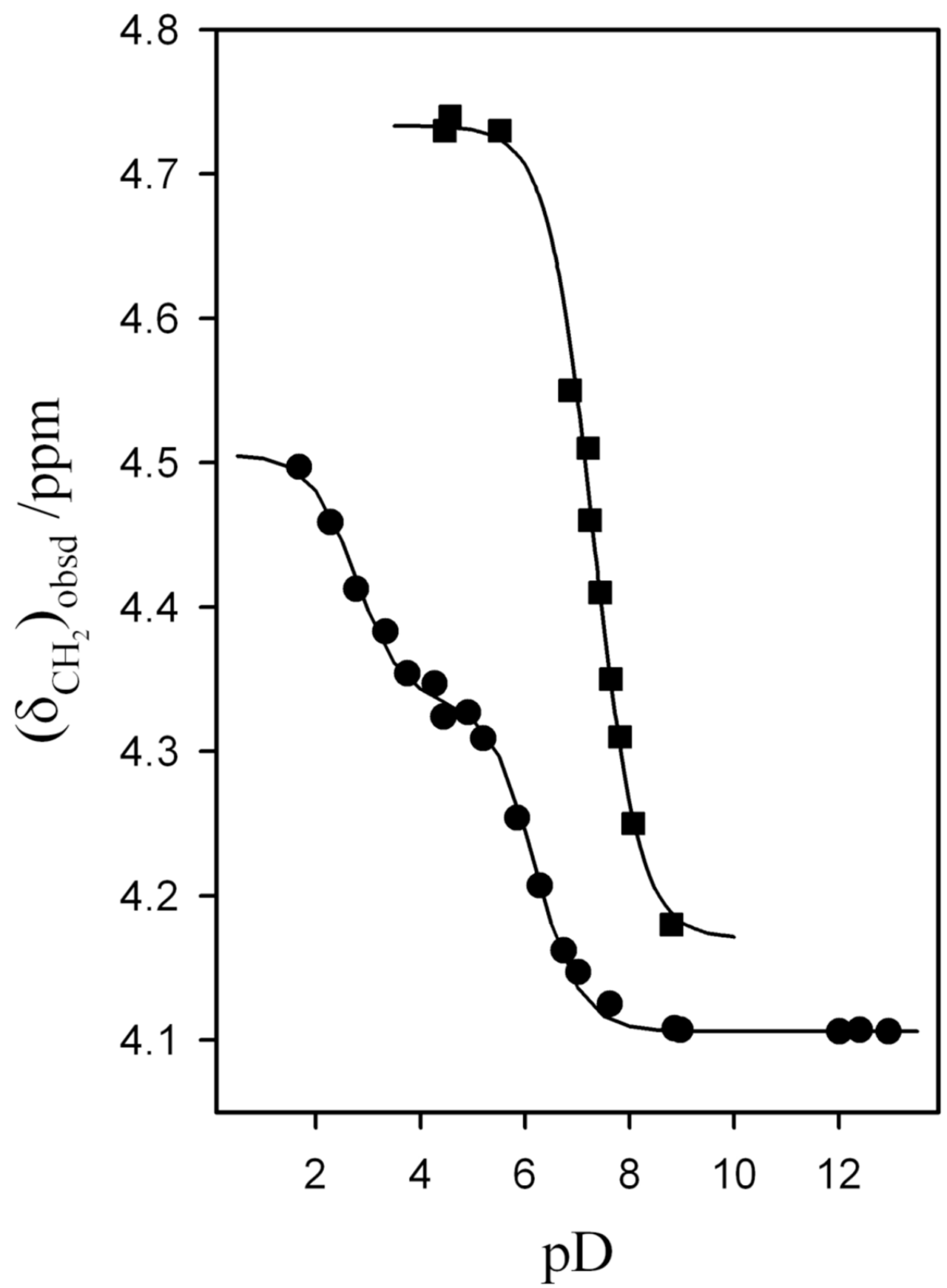

Figure 1.

The dependence on $\mathrm{pD}$ of $\left(\delta_{\mathrm{CH}_{2}}\right)_{\text {obsd }}(\mathrm{ppm})$, for the $-\mathrm{CH}_{2}$ - hydrogen of the imine formed in $\mathrm{D}_{2} \mathrm{O}$ that contains: $(\boldsymbol{\bullet}), 0.1 \mathrm{M}$ glycine methyl ester and $3 \mathrm{M}$ acetone; $(\bullet)$, glycine $(0.1-2.0 \mathrm{M}$, depending upon the $\mathrm{pD}$ ) and $0.8 \mathrm{M}$ phenylglyoxylate at $25^{\circ} \mathrm{C}$ and $I=1.0(\mathrm{KCl})$. The solid lines show the fit of the data to eq 7 derived for Scheme $2(\boldsymbol{\square})$, or to eq 8 derived for Scheme 3 (•). 


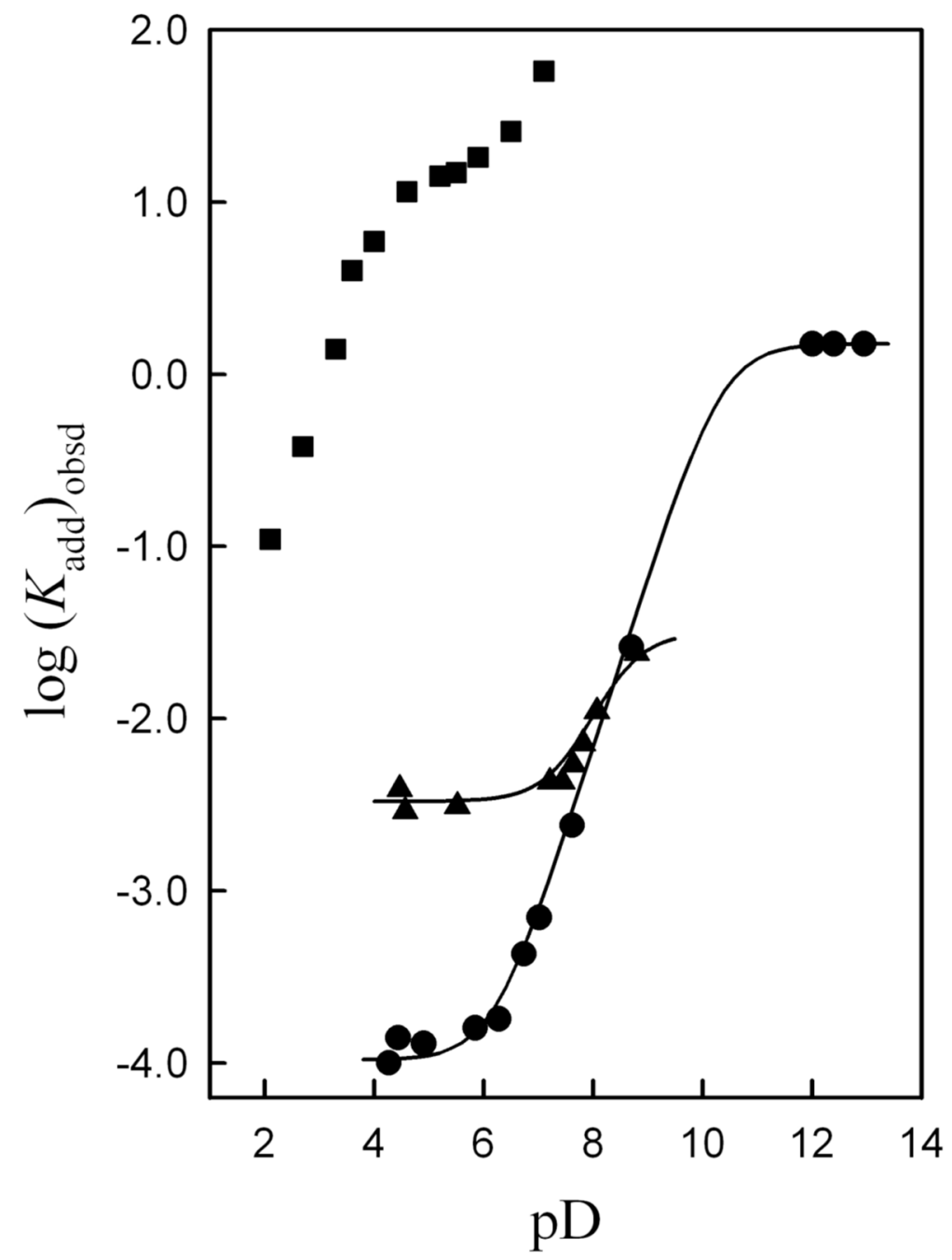

Figure 2.

Logarithmic dependence of $\left(K_{\text {add }}\right)_{\text {obsd }}\left(\mathrm{M}^{-1}\right)$ on $\mathrm{pD}$ for conversion of glycine and glycine methyl ester to the corresponding imines in $\mathrm{D}_{2} \mathrm{O}$ at $25^{\circ} \mathrm{C}$ and $I=1.0(\mathrm{KCl})$. Key: Reaction of glycine with phenylglyoxylate $(\bullet)$. The solid line was calculated using eq $9(\mathrm{X}=\mathbf{2})$ and the equilibrium constants from Table 1 . Reaction of glycine methyl ester with acetone $(\boldsymbol{\Delta})$. The solid line was calculated using eq $9(\mathrm{X}=\mathbf{1})$ and the equilibrium constants from Table 1. Reaction of glycine with 5'-deoxypyridoxal ( $\mathbf{}) .15$ 

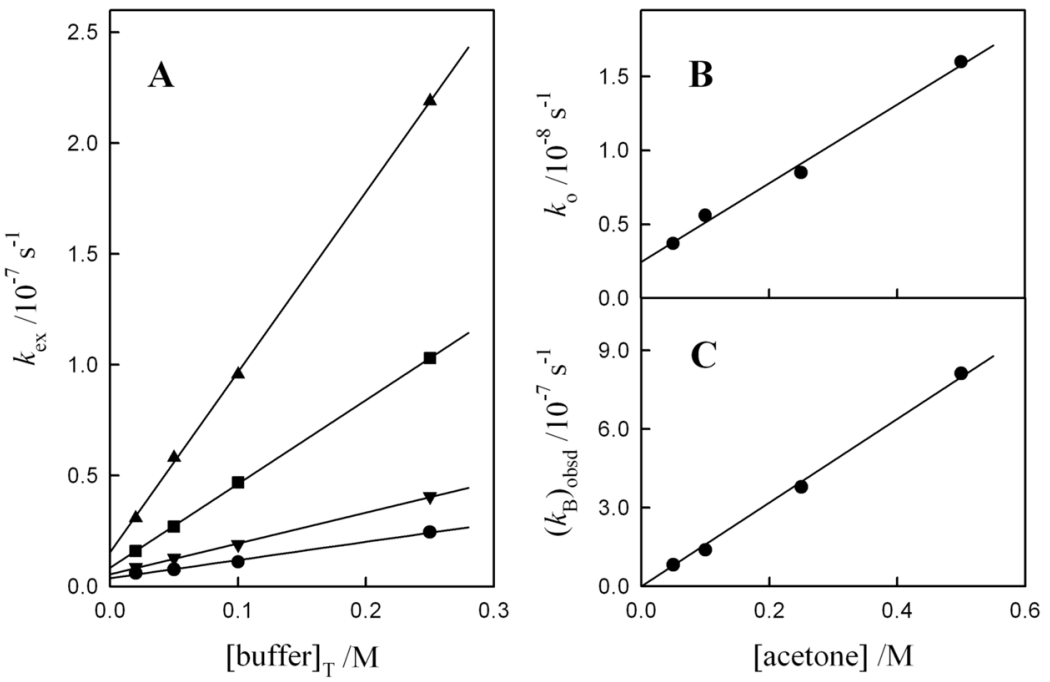

Figure 3.

(A) Dependence of $k_{\mathrm{ex}}\left(\mathrm{s}^{-1}\right)$ for exchange of the first $\alpha$-proton of glycine methyl ester in the presence of acetone on the total concentration of acetate buffer $(\mathrm{pD}=5.56)$ in $\mathrm{D}_{2} \mathrm{O}$ at $25^{\circ} \mathrm{C}$ and $I=1.0(\mathrm{KCl})$. Key: $(\bullet) 0.05 \mathrm{M}$ acetone; $(\boldsymbol{\nabla}) 0.10 \mathrm{M} ;(\boldsymbol{\bullet}) 0.25 \mathrm{M} ;(\boldsymbol{\Delta}) 0.50 \mathrm{M}$. (B)

Dependence of the intercepts of the linear correlations in Figure 3A $\left(k_{\mathrm{O}}\right)$ on [acetone]. The slope of Figure 3B gives $\left(k_{\mathrm{w}}\right)_{\text {obsd }}\left(\mathrm{M}^{-1} \mathrm{~s}^{-1}\right)$ for the acetone-catalyzed deuterium exchange reaction at $\mathrm{pD}$ 5.56. (C) Dependence of the slopes of the linear correlations in Figure 3A $\left(k_{\mathrm{B}}\right)_{\text {obsd }}$ on [acetone]. The slope gives $\left(k_{\mathrm{B}}^{\mathrm{T}}\right)_{\text {obsd }}\left(\mathrm{M}^{-2} \mathrm{~s}^{-1}\right)$ for a termolecular acetone and buffer-catalyzed deuterium exchange reaction at $\mathrm{pD} 5.56$. 


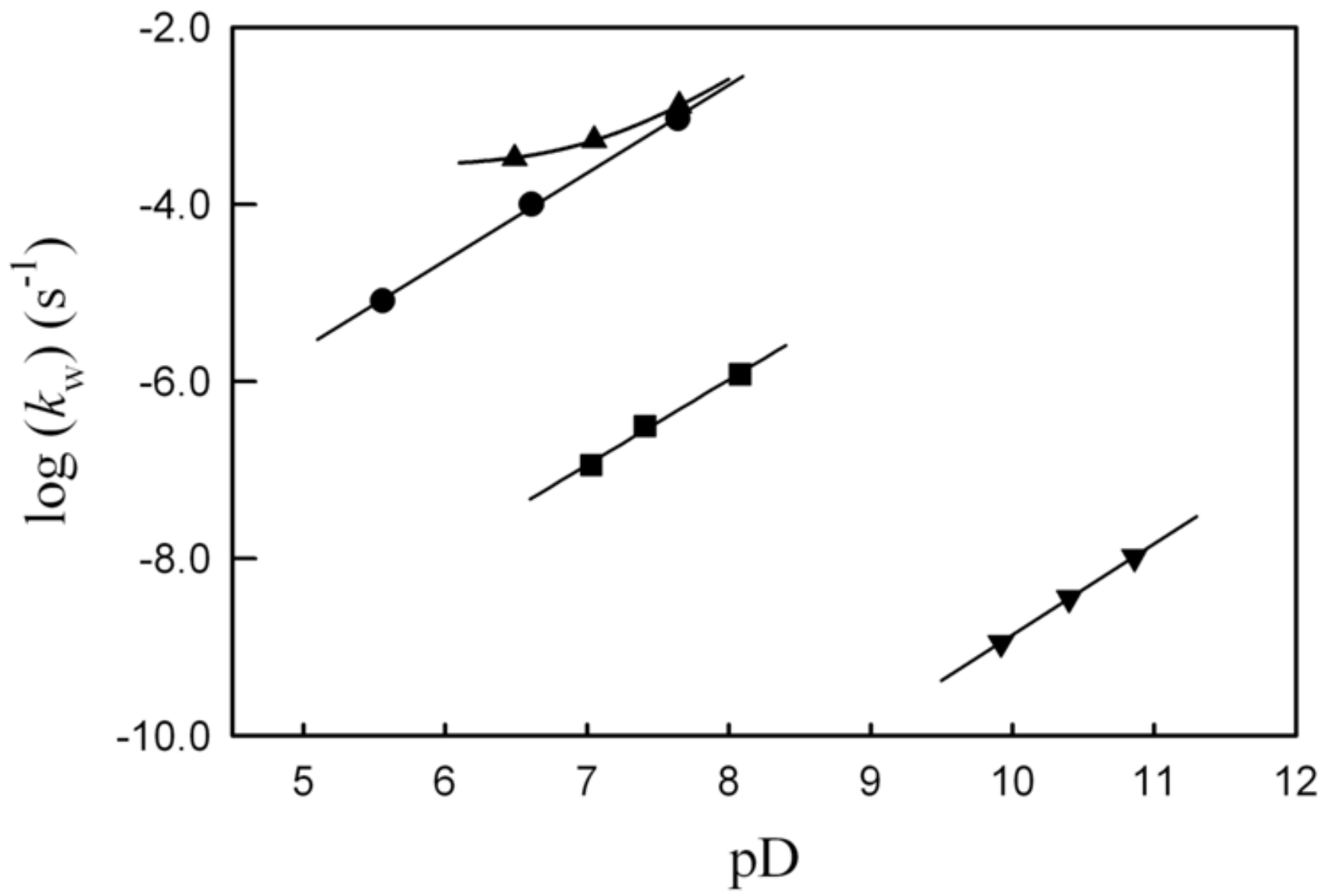

Figure 4.

pD-rate profiles of $k_{\mathrm{W}}\left(\mathrm{s}^{-1}\right)$ for exchange for deuterium of: (a) ( $\bullet$ ), the first $\alpha-\mathrm{CH}_{2}$ - hydrogen of 1-D; (b) ( $\mathbf{\Delta}$ ), the first $\alpha-\mathrm{CH}_{2}$ - hydrogen of 2-D. (c) (घ), the first $\alpha-\mathrm{CH}_{2}$ - hydrogen of Nprotonated glycine methyl ester; ${ }^{1}(\boldsymbol{\nabla})$, the first $\alpha-\mathrm{CH}_{2}$ - hydrogen of $\mathrm{N}$-protonated glycine. ${ }^{1}$ 


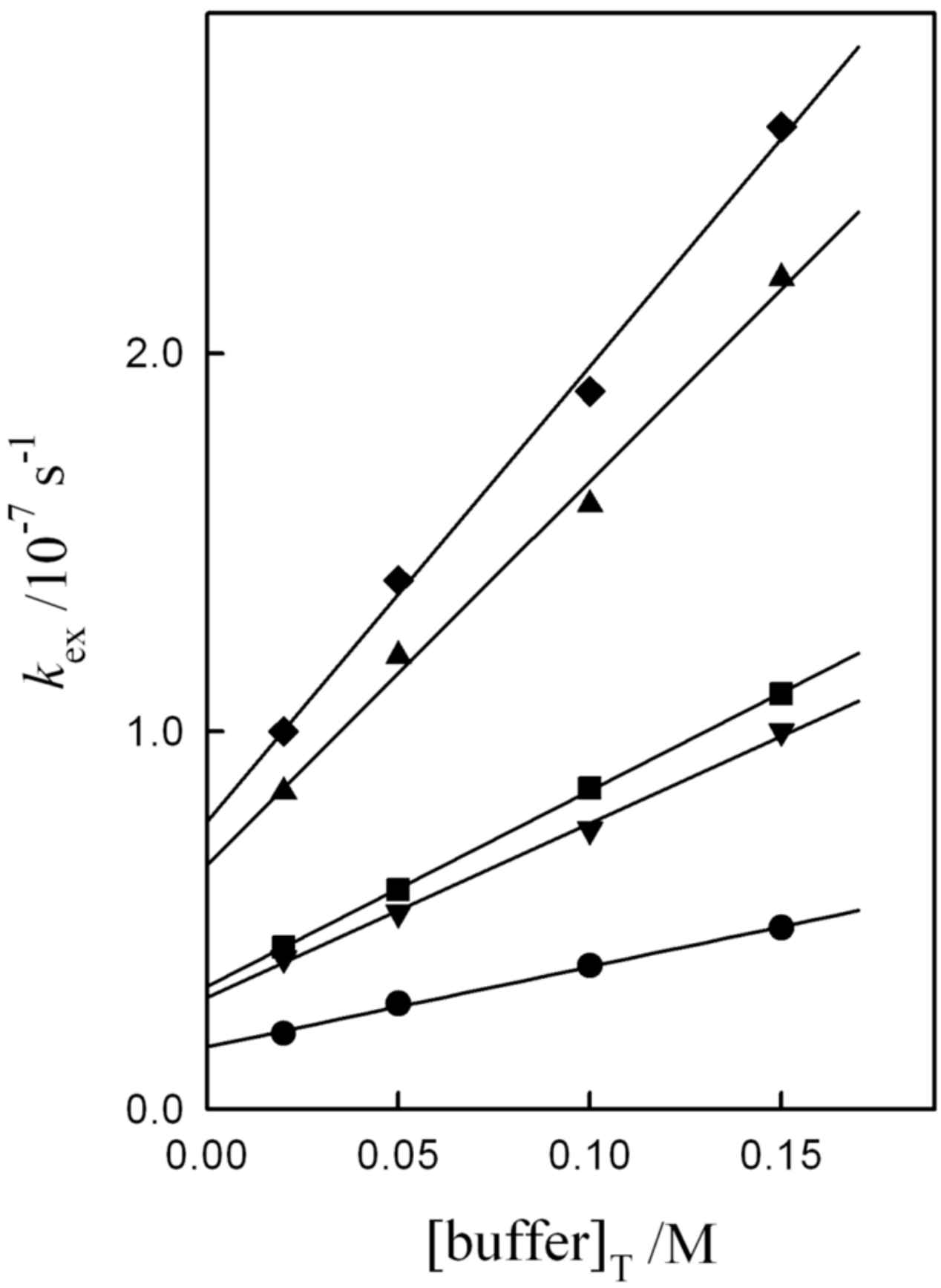

Figure 5.

Dependence of $k_{\mathrm{ex}}\left(\mathrm{s}^{-1}\right)$ for exchange for deuterium of the first $\alpha$-proton of glycine in the presence of phenylglyoxylate on the total concentration of phosphate buffer at $\mathrm{pD}=7.65$ in $\mathrm{D}_{2} \mathrm{O}$ at $25^{\circ} \mathrm{C}$ and $I=1.0(\mathrm{KCl})$. Key: $(\bullet), 0.1 \mathrm{M}$ phenylglyoxylate; $(\boldsymbol{\nabla}), 0.20 \mathrm{M} ;(\boldsymbol{\bullet}), 0.25 \mathrm{M}$; $(\boldsymbol{\Lambda}), 0.40 \mathrm{M} ;(\diamond), 0.50 \mathrm{M}$. 


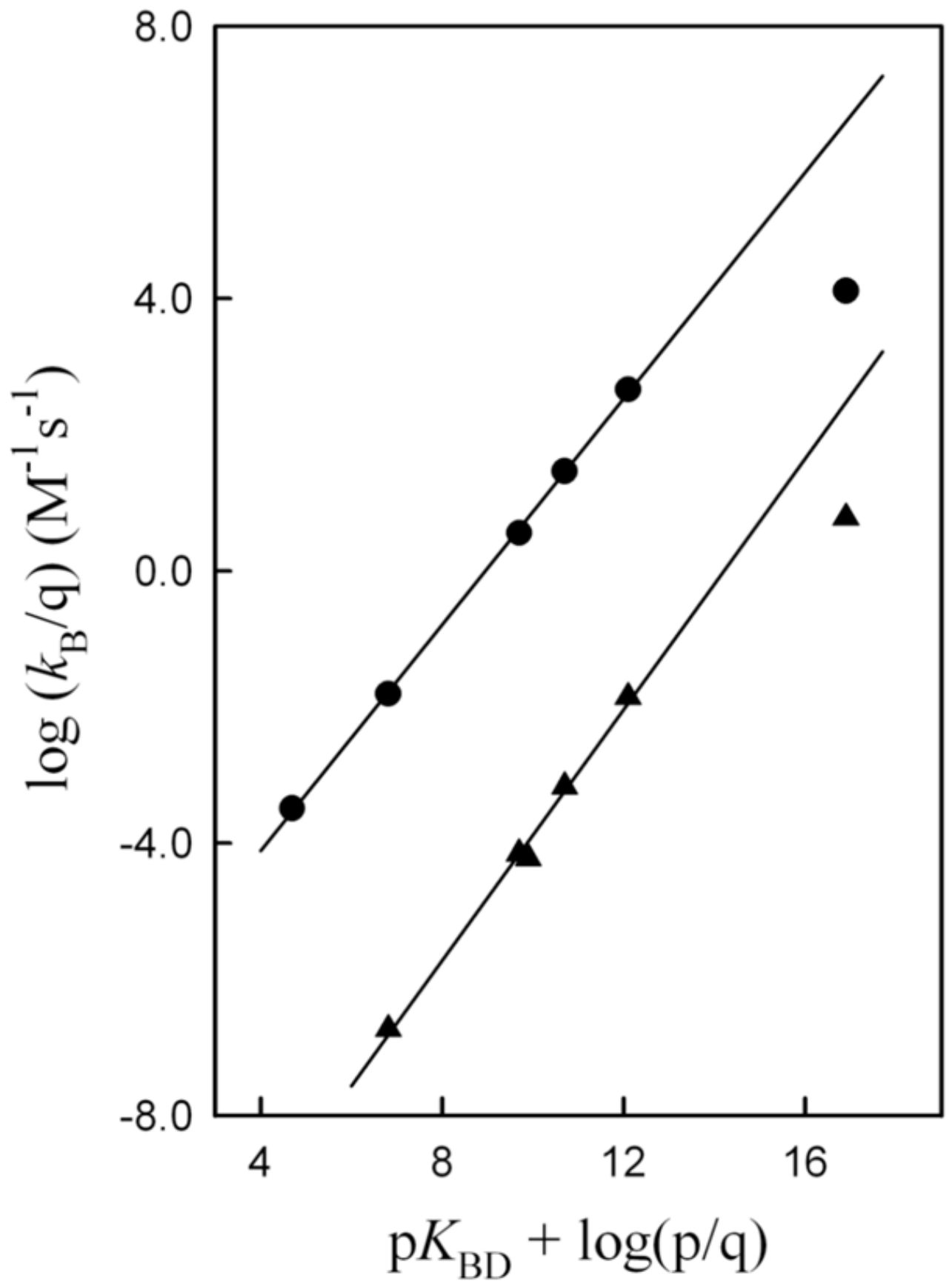

Figure 6.

Statistically corrected Brønsted correlations for deprotonation of 1-D $(\bullet)$ and N-protonated glycine methyl ester $(\boldsymbol{\Delta})$ by buffer bases and $\mathrm{DO}^{-}$in $\mathrm{D}_{2} \mathrm{O}$, where $\mathrm{q}$ and $\mathrm{p}$ are equal to the number of chemically equivalent basic sites in the reactant and equivalent acidic hydrogen in the product, respectively. 
<smiles></smiles><smiles></smiles><smiles>[2H]C(C(=O)OC)[N+](=O)[O-]</smiles>

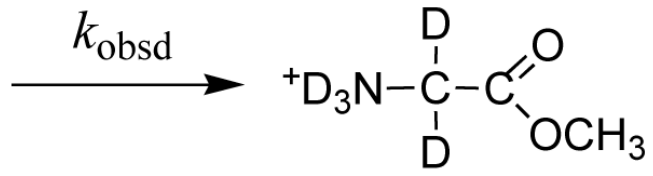

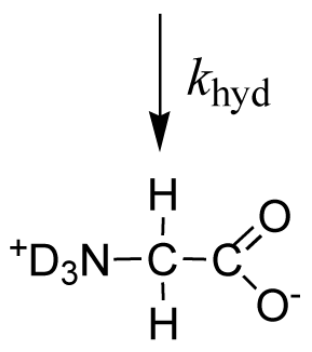<smiles>[Y10][Y6](=O)C(C(=O)[O-])[N+](=O)[O-]</smiles><smiles>[R]C([Y6])(C)[14C](=O)[O-]</smiles>

Scheme 1. 


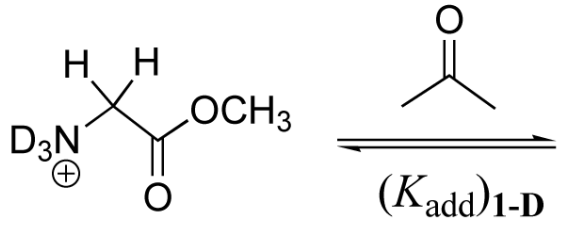<smiles>[R9][NH+]([R9])C(=O)OC</smiles>

\section{1-D}

$a_{\mathrm{D}} /\left(K_{\mathrm{a}}\right)_{\text {MeOGlyD }} \|$

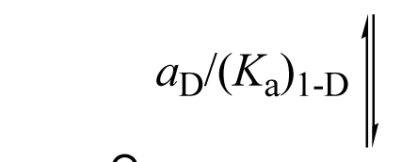<smiles>COC(=O)C[N+](=O)[O-]</smiles><smiles>CCCC(C)=O</smiles><smiles>COC(=O)CN=C(C)C</smiles>

Scheme 2. 


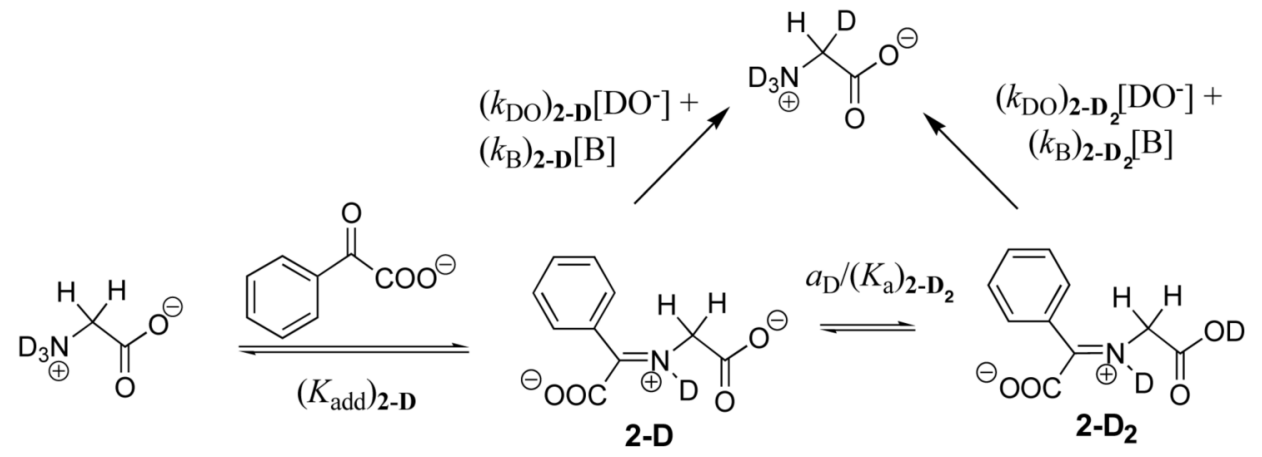
$a_{\mathrm{D}} /\left(K_{\mathrm{a}}\right)_{\mathrm{GlyD}} \|$<smiles>O=C(O[Na])C([O-])[N+](=O)[O-]</smiles><smiles></smiles><smiles>O=C([O-])C(=O)N=C(C(=O)[O-])c1ccccc1</smiles>

Scheme 3. 
<smiles>[B]CC=CC=CC(C)C(=O)OC</smiles><smiles>COC(=O)[NH+]=C(C)C</smiles><smiles>O=C([O-])C(=O)c1ccccc1</smiles><smiles>NCC(=O)[O-]</smiles><smiles>[NH2+]C(C(=O)[O-])=C([O-])c1ccccc1</smiles>

2-H

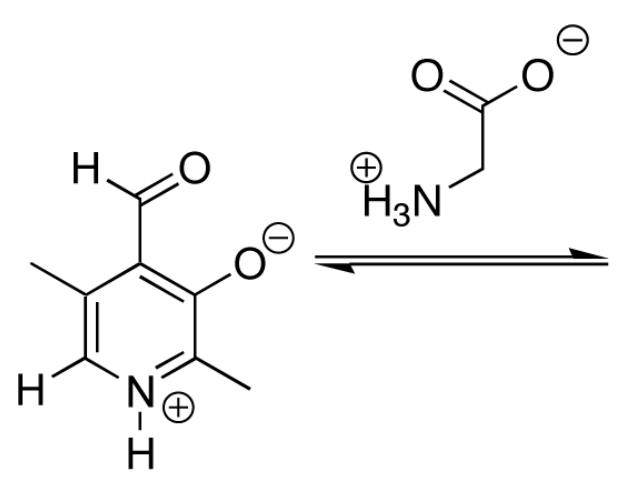

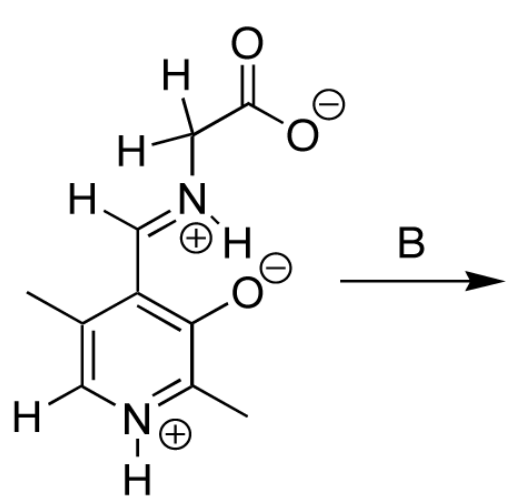

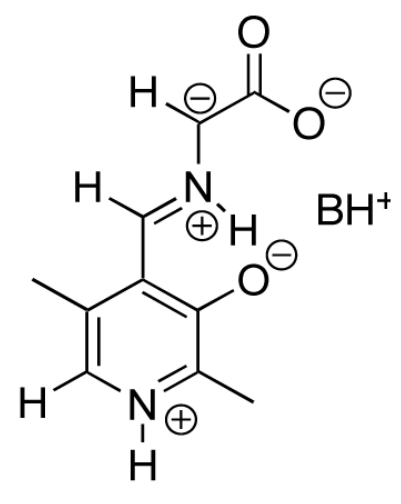

Chart 1. 

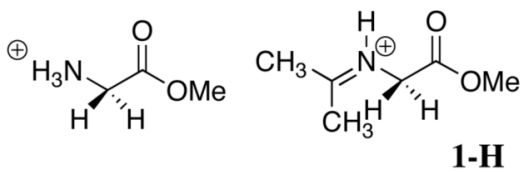

$$
k_{\mathrm{HO}}\left(\mathrm{M}^{-1} \mathrm{~s}^{-1}\right)
$$

$4.1($ ref 1$)$

$9 \times 10^{4}(\operatorname{ref} 2)$
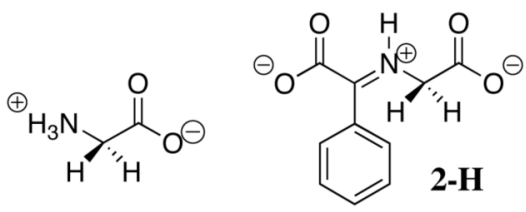

$k_{\mathrm{HO}}\left(\mathrm{M}^{-1} \mathrm{~s}^{-1}\right) \quad 4.5 \times 10^{-5}($ ref 1$) \quad 2.7 \times 10^{4}$

$\mathrm{p} K_{\mathrm{CH}}=\left(\frac{10.2-\log k_{\mathrm{HO}}}{0.44}\right)$

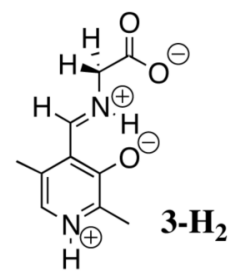

$750($ ref 15)

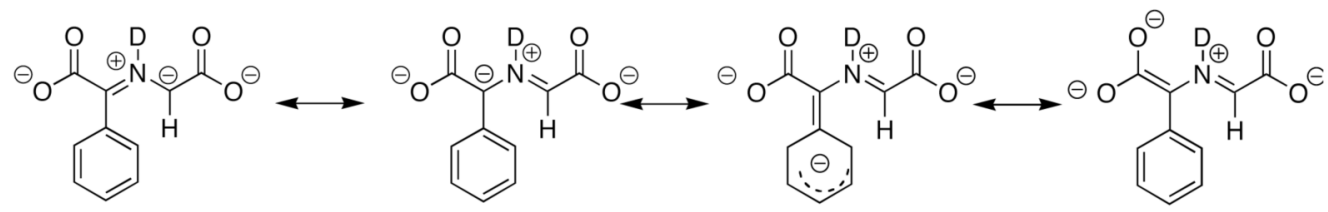

Chart 2. 
<smiles>COC(=O)C[13CH2]</smiles><smiles>CC(=O)O[18F]</smiles>

$k_{\mathrm{o}}\left(\mathrm{s}^{-1}\right)$

$4 \times 10^{-7}$

$3 \times 10^{-8}$

pD 7.6<smiles>[13CH3]C(=O)[O-]</smiles>

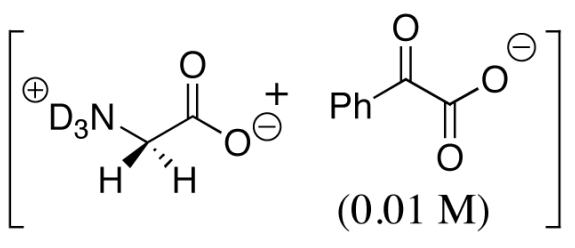<smiles>[R]O[Na]</smiles>

$k_{\mathrm{o}}\left(\mathrm{s}^{-1}\right)$

$6 \times 10^{-12}$

$1.5 \times 10^{-9}$

$1.9 \times 10^{-5}(\operatorname{ref} 15)$

pD 7.6 (pH 7.1)

Chart 3. 


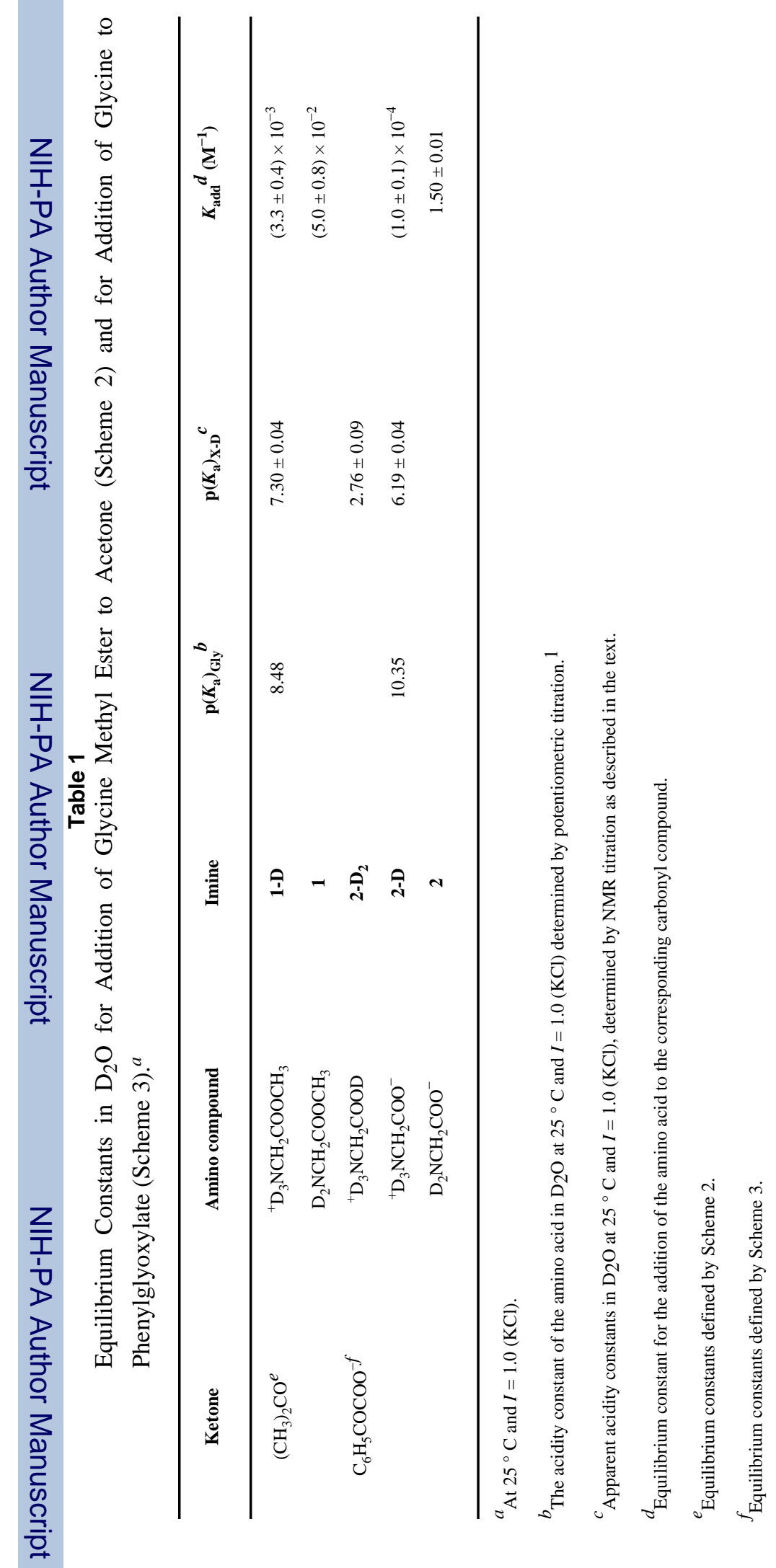




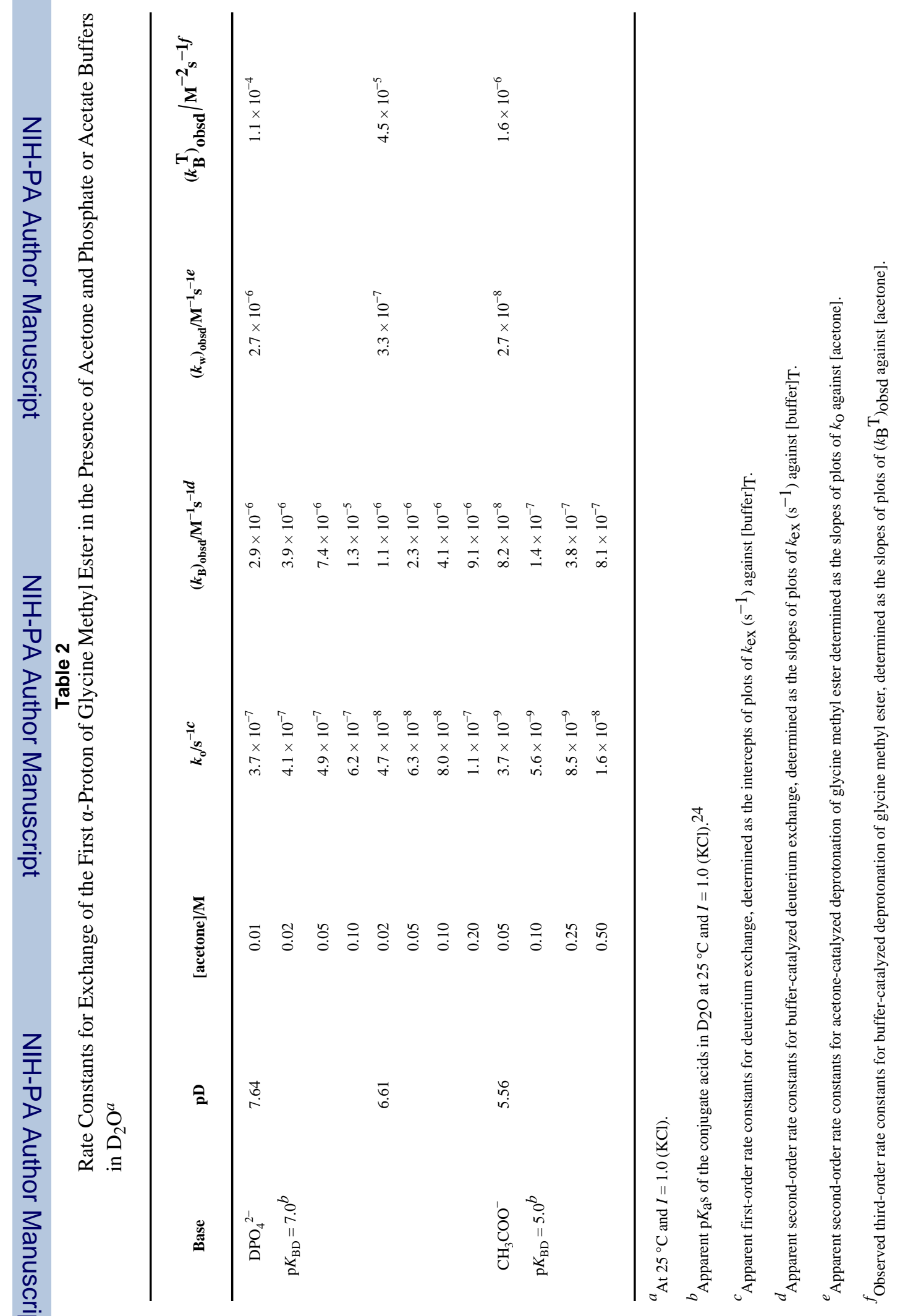




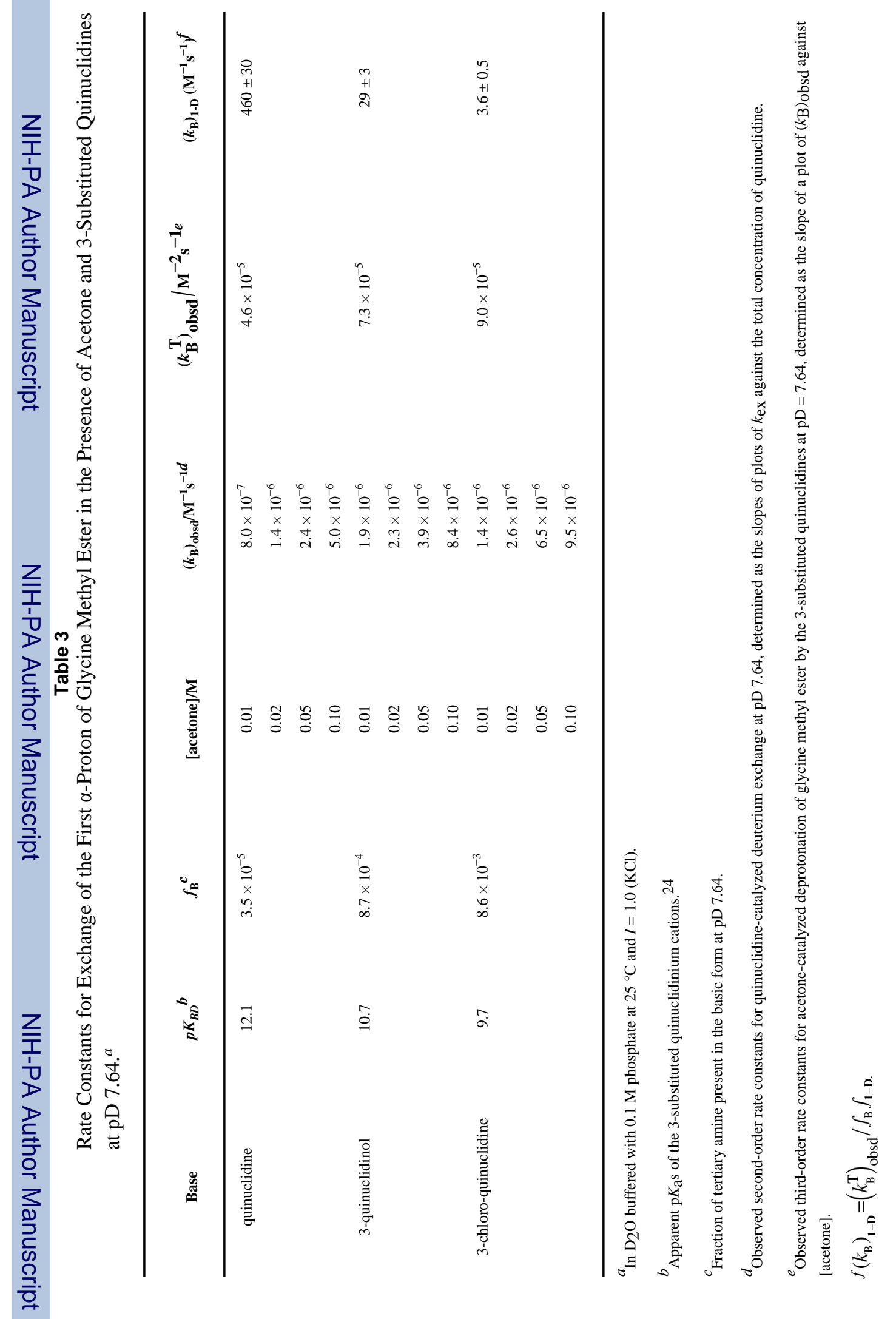




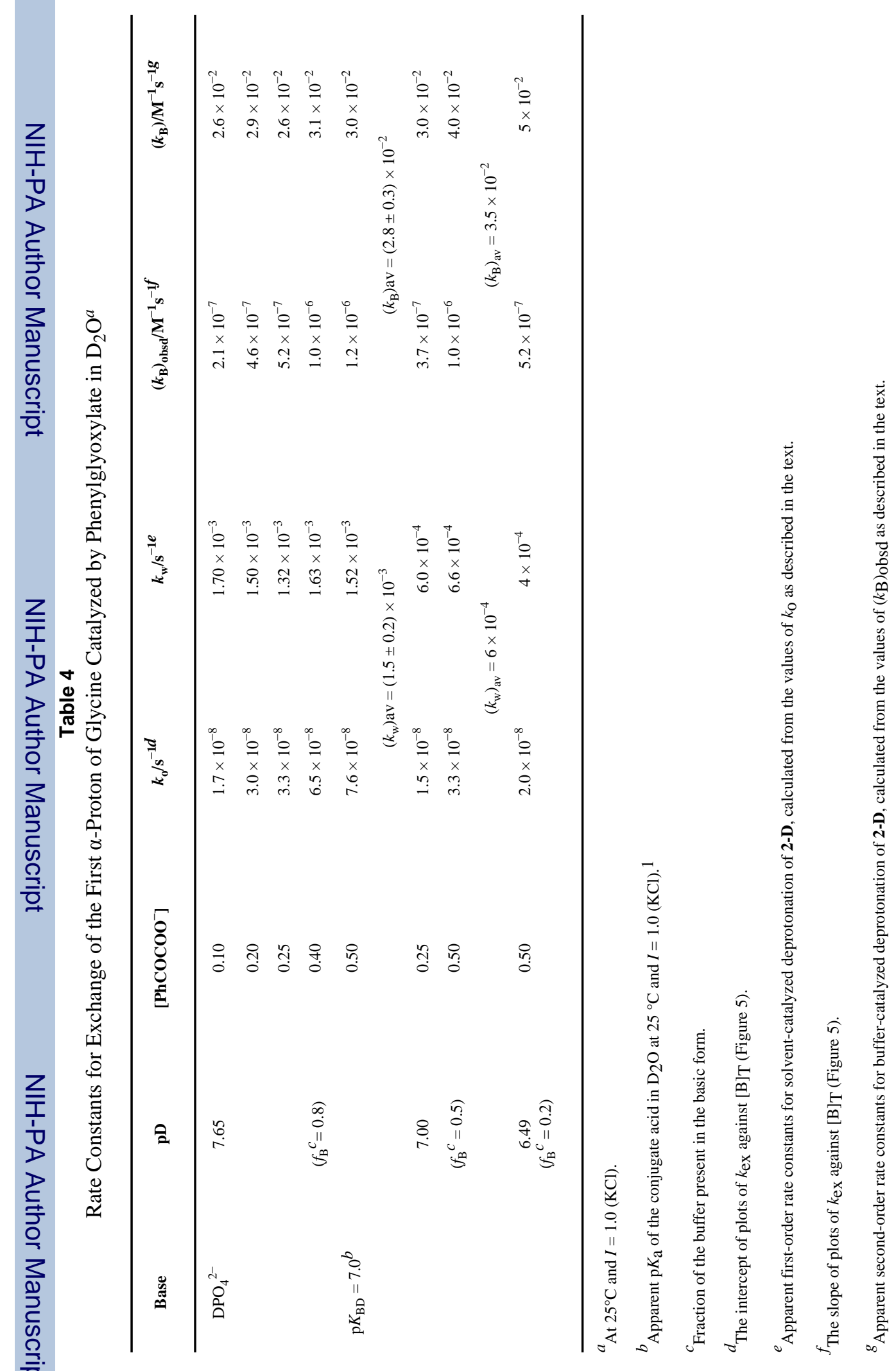

J Am Chem Soc. Author manuscript; available in PMC 2009 May 20. 
Table 5

Second-Order Rate Constants for Carbon Deprotonation of the Iminium Ions of Glycine methyl ester and acetone and of Glycine and Phenylglyoxylate in $\mathrm{D}_{2} \mathrm{O}^{a}$

\begin{tabular}{|c|c|c|c|}
\hline Base catalyst & $\mathrm{p} K_{\mathrm{BD}}^{b}$ & Iminium ion & $k_{\mathrm{B}}\left(\mathrm{M}^{-1} \mathrm{~s}^{-1}\right)^{c}$ \\
\hline \multirow[t]{3}{*}{$\mathrm{DO}^{-}$} & 16.6 & 1-D & $(1.3 \pm 0.1) \times 10^{4}$ \\
\hline & & 2-D & $(1.7 \pm 0.1) \times 10^{4}$ \\
\hline & & 2-D & $\approx(3.0 \pm 0.7) \times 10^{8}$ \\
\hline quinuclidine & 12.1 & 1-D & $460 \pm 30$ \\
\hline 3-quinuclidinol & 10.7 & 1-D & $29 \pm 3$ \\
\hline 3-chloroquinuclidine & 9.7 & 1-D & $3.6 \pm 0.5$ \\
\hline \multirow[t]{3}{*}{$\mathrm{DPO}_{4}{ }^{2-}$} & 7.0 & 1-D & $(4.7 \pm 0.2) \times 10^{-2}$ \\
\hline & & 2-D & $(2.8 \pm 0.1) \times 10^{-2}$ \\
\hline & & 2-D 2 & $\approx(1.1 \pm 0.3) \times 10^{2}$ \\
\hline $\mathrm{CH}_{3} \mathrm{COO}^{-}$ & 5.0 & 1-D & $(6.5 \pm 0.2) \times 10^{-4}$ \\
\hline
\end{tabular}

${ }^{a}$ At $25^{\circ} \mathrm{C}$ and $I=1.0(\mathrm{KCl})$. The quoted errors are standard deviations.

${ }^{b}$ Apparent $\mathrm{p} K_{\mathrm{a}}$ of the conjugate acid of the base catalyst in $\mathrm{D}_{2} \mathrm{O}$ at $25^{\circ} \mathrm{C}$ and $I=1.0(\mathrm{KCl}) .{ }^{24}$

${ }^{c}$ Second-order rate constants for deprotonation of the iminium ion by the base catalyst, calculated from kinetic data as described in the text. 